\title{
TLR4 Deficiency Impairs Oligodendrocyte Formation in the Injured Spinal Cord
}

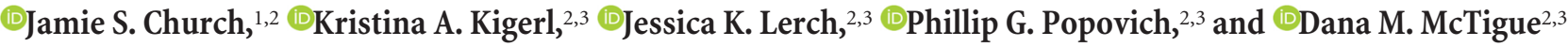 \\ ${ }^{1}$ Neuroscience Graduate Program, ${ }^{2}$ Center for Brain and Spinal Cord Repair, and ${ }^{3}$ Department of Neuroscience, Ohio State University, Columbus, Ohio \\ 43210
}

Acute oligodendrocyte (OL) death after traumatic spinal cord injury (SCI) is followed by robust neuron-glial antigen 2 (NG2)-positive OL progenitor proliferation and differentiation into new OLs. Inflammatory mediators are prevalent during both phases and can influence the fate of NG2 cells and OLs. Specifically, toll-like receptor (TLR) 4 signaling induces OL genesis in the naive spinal cord, and lack of TLR4 signaling impairs white matter sparing and functional recovery after SCI. Therefore, we hypothesized that TLR4 signaling may regulate oligodendrogenesis after SCI. C3H/HeJ (TLR4-deficient) and control (C3H/HeOuJ) mice received a moderate midthoracic spinal contusion. TLR4-deficient mice showed worse functional recovery and reduced OL numbers compared with controls at $24 \mathrm{~h}$ after injury through chronic time points. Acute OL loss was accompanied by reduced ferritin expression, which is regulated by TLR4 and needed for effective iron storage. TLR4-deficient injured spinal cords also displayed features consistent with reduced OL genesis, including reduced NG2 expression, fewer BrdU-positive OLs, altered BMP4 signaling and inhibitor of differentiation 4 (ID4) expression, and delayed myelin phagocytosis. Expression of several factors, including IGF-1, FGF2, IL-1 $\beta$, and PDGF-A, was altered in TLR4-deficient injured spinal cords compared with wild types. Together, these data show that TLR4 signaling after SCI is important for OL lineage cell sparing and replacement, as well as in regulating cytokine and growth factor expression. These results highlight new roles for TLR4 in endogenous SCI repair and emphasize that altering the function of a single immune-related receptor can dramatically change the reparative responses of multiple cellular constituents in the injured CNS milieu.

Key words: growth factor; inflammation; macrophage; microglia; myelin; phagocytosis

\section{Significance Statement}

Myelinating cells of the CNS [oligodendrocytes (OLs)] are killed for several weeks after traumatic spinal cord injury (SCI), but they are replaced by resident progenitor cells. How the concurrent inflammatory signaling affects this endogenous reparative response is unclear. Here, we provide evidence that immune receptor toll-like receptor 4 (TLR4) supports OL lineage cell sparing, long-term OL and OL progenitor replacement, and chronic functional recovery. We show that TLR4 signaling is essential for acute iron storage, regulating cytokine and growth factor expression, and efficient myelin debris clearance, all of which influence $0 \mathrm{~L}$ replacement. Importantly, the current study reveals that a single immune receptor is essential for repair responses after SCI, and the potential mechanisms of this beneficial effect likely change over time after injury.

\section{Introduction}

Oligodendrocytes (OLs), the myelinating cells of the CNS, die after spinal cord injury (SCI) at the time of impact and for several weeks thereafter (Crowe et al., 1997; Grossman et al., 2001). OL

\footnotetext{
Received Feb. 1, 2016; revised April 29, 2016; accepted May 5, 2016.

Author contributions: J.S.C., K.A.K., P.G.P., and D.M.M. designed research; J.S.C., J.K.L., and D.M.M. performed research; J.S.C., K.A.K., J.K.L., P.G.P., and D.M.M. analyzed data; J.S.C., K.A.K., J.K.L., P.G.P., and D.M.M. wrote the paper.

This work was supported by National Institutes of Health/National Institute of Neurological Disorders and Stroke Grants R01-NS059776 (D.M.M.), R01-NS082095 (D.M.M.), and P30-NS045758 (D.M.M.), Ray W. Poppleton Endowment (P.G.P.), and the Center for Brain and Spinal Cord Repair. We thank A. Todd Lash, Ping Wei, Andrea Houchin, Rochelle Deibert, and Feng Qin Yin for excellent technical assistance. Appreciation is also extended to Dr. Paolo Fadda at the James Nucleic Acid Shared Resource Core Facility (Ohio State University) for his excellent assistance with RT-PCR analysis.
}

loss contributes to demyelination, which impairs axon conduction and neurological function. New OLs are produced after SCI and arise from neuron-glial antigen 2 -positive $\left(\mathrm{NG}^{+}\right)$oligodendrocyte progenitor cell (OPC) proliferation and differentiation. This reparative response restores OL numbers to baseline in spared tissue and results in significantly greater OLs along the lesion border (Tripathi and McTigue, 2007; Hesp et al., 2015).

The authors declare no competing financial interests.

Correspondence should be addressed to Dr. Dana McTigue, Department of Neuroscience, Ohio State University, 692 Biomedical Research Tower, 460 West Twelfth Avenue, Columbus, OH 43210. E-mail: Dana.McTigue@osumc.edu.

DOI:10.1523/JNEUROSCI.0353-16.2016

Copyright $\odot 2016$ the authors $\quad 0270-6474 / 16 / 366352-13 \$ 15.00 / 0$ 
New OLs myelinate spinal axons for at least 3 months after injury and thereby contribute to spontaneous endogenous repair (Hesp et al., 2015). Although developmental oligodendrogenesis is guided by known intrinsic (transcriptional changes) and extrinsic (growth factors, cytokines) cues, the signals directing this endogenous repair response after adult SCI are unknown. Determining the mechanisms controlling OL replacement after SCI will provide insight into glial replacement in the injured adult $\mathrm{CNS}$ and may guide therapeutic development for other forms of neurological disease involving OL loss or demyelination.

Key players in post-SCI OL replacement and remyelination likely include inflammation and activated macrophages. For instance, activated macrophages express pro-oligogenic growth factors and clear lipid debris, which was shown to be essential for OL genesis and remyelination after toxin-induced demyelination (Kotter et al., 2005, 2006). Activated macrophages can also shuttle iron-containing ferritin to OPCs in vivo, which is needed for differentiation of OPCs into myelinating OLs (Schonberg et al., 2012). A key inflammatory signaling pathway is mediated by the toll-like receptor 4 (TLR4), which can influence all these features, including iron regulation (Carraway et al., 1998; Yang et al., 2002; Theurl et al., 2008; Recalcati et al., 2010; Layoun and Santos, 2012; Urrutia et al., 2013), cytokine secretion (Aderem and Ulevitch, 2000; Wells et al., 2003a,b), phagocytosis (Vallières et al., 2006; Boivin et al., 2007; Li et al., 2014), and oligodendrogenesis (Schonberg et al., 2007; Schonberg and McTigue, 2009). Our previous work showed that TLR4 is essential after SCI, because mice with deficient TLR4 signaling displayed exacerbated white matter pathology and impaired functional recovery (Kigerl et al., 2007). In other work, Schonberg et al. (2007) demonstrated that activating intraspinal TLR4 signaling induced OL progenitor proliferation and new OL genesis (Schonberg and McTigue, 2009). Because microglia and macrophages express by far the greatest amount of TLR4 in the spinal cord (and OLs do not express TLR4), they most likely are responsible for the beneficial effects of intraspinal TLR4 activation (Lehnardt et al., 2002; Kigerl et al., 2007).

The link between TLR4 activation and OL genesis in the normal spinal cord and increased white matter loss after SCI in the absence of TLR4 suggest that post-SCI TLR4 signaling may induce a favorable post-SCI environment for OL survival and formation. This is especially true when considering that TLR4 ligands, such as heme, fibronectin, and high-mobility group protein 1 (HMGB1), are abundant in the injured spinal cord (Kigerl et al., 2009). Thus, we used mice deficient in TLR4 signaling to test the hypothesis that TLR4 activation regulates OL survival and replacement after SCI. The data reveal that TLR4 signaling is protective for OLs and OPCs acutely after SCI and is important for the normal timing and response of OL lineage cells; it also facilitates myelin debris clearance and regulates post-SCI growth factor expression. Thus, TLR4 appears central to many proreparative endogenous responses in the injured adult spinal cord and may represent an attractive therapeutic target to enhance recovery from injury.

\section{Materials and Methods}

Animals. All surgical and postoperative care procedures were performed in accordance with the Ohio State University Institutional Animal Care and Use Committee. Twelve-week-old male C3H/HeJ $(n=47)$ and $\mathrm{C} 3 \mathrm{H} / \mathrm{HeOuJ}(n=44)$ mice were obtained from The Jackson Laboratory. The $\mathrm{C} 3 \mathrm{H} / \mathrm{HeJ}$ mice have a point mutation at a single residue in the cytoplasmic tail of the TLR4 molecule; although there may be compensatory changes developed in response to the mutations, TLR4 signaling in
$\mathrm{C} 3 \mathrm{H} / \mathrm{HeJ}$ mice has been verified to be deficient (Poltorak et al., 1998). $\mathrm{C} 3 \mathrm{H} / \mathrm{HeOuJ}$ mice have functional TLR4 signaling, and, although they are not littermates, they are the line typically used as wild-type (WT) controls for $\mathrm{C} 3 \mathrm{H} / \mathrm{HeJ}$ [TLR4-deficient (TLR4d)] mice, including in previous work from our laboratory (Kigerl et al., 2007). In total, five WT and eight TLR4d mice were lost as a result of problems with anesthesia, surgeon error, or bladder expression as detailed below.

SCI. During initial studies with these mice, difficulties with anesthesia led to a loss of six mice (mice were not reaching adequate levels of unconsciousness and were given multiple anesthesia injections). After determining a higher than usual initial dose of ketamine was needed, all mice were anesthetized with an intraperitoneal mixture of ketamine (180 $\mathrm{mg} / \mathrm{kg}) /$ xylazine $(10 \mathrm{mg} / \mathrm{kg})$ after which a partial laminectomy was performed at vertebral level T9. All mice received a moderate spinal contusion injury (75 kDyn) using the Infinite Horizons device (Precision Systems and Instrumentation). An additional six mice were lost as a result of surgical complications. Postoperatively, animals were hydrated with $2 \mathrm{ml}$ of saline (subcutaneously) and were given prophylactic antibiotics $(0.1 \mathrm{ml}$ of gentamicin, s.c.) for $5 \mathrm{~d}$. Bladders were voided manually twice daily for duration of the study. One mouse was lost during bladder expression.

5-Bromo-2'-deoxyuridine administration. To label proliferating cells, the thymidine analog 5-bromo- $2^{\prime}$-deoxyuridine (BrdU) $(50 \mathrm{mg} / \mathrm{kg}$ in sterile saline; Sigma-Aldrich) was injected intraperitoneally once a day on 1-7 d post-injury (dpi).

Behavioral analysis. Hindlimb locomotor function was assessed using the Basso Mouse Scale (BMS; Basso et al., 2006) and automated horizontal ladder. Mice were tested using the BMS at $-1,1,7,14,21,28,35$, and $42 \mathrm{dpi}$ by evaluators blinded to groups. Individual hindlimb scores were averaged for each animal at each time point. Once mice regained plantar stepping ability (BMS score of 4), they were tested using the automated horizontal ladder on $-1,13,20,27,34$, and $41 \mathrm{dpi}$. The horizontal ladder has rungs spaced $0.85 \mathrm{~cm}$ apart for $86.25 \mathrm{~cm}$. Each foot slip made contact with a metal pan $0.5 \mathrm{~cm}$ below the rungs and was counted by the apparatus as a misstep. During baseline acclimation to the ladder, the optimal distance of the pan below the rungs was determined based on its reliability to register a misstep while not providing a convenient alternative to place the paws while walking. Mice were motivated to walk along the ladder by placing a dark box at the far end. Scores for each animal were the average of three trials at each time point. Locomotor function in both tasks was normal before injury in both genotypes.

Tissue processing. Mice for immunohistochemical analyses were killed at $1,7,14$, or $21 \mathrm{dpi}$; a group of naive mice was included as non-injury controls ( $n=3-5$ per genotype per time point). All mice were anesthetized with a lethal mixture of ketamine/xylazine $(1.5 \times$ the surgical dose $)$ and then transcardially perfused with $0.1 \mathrm{~m}$ PBS, followed by $4 \%$ paraformaldehyde (PFA). Fixed animals were dissected for spinal cord tissue centered on the lesion site. Spinal cords were postfixed in $4 \%$ PFA for $2 \mathrm{~h}$, transferred to $0.2 \mathrm{~m}$ phosphate buffer overnight, and then cryopreserved in $30 \%$ sucrose solution in water for $3 \mathrm{~d}$. Frozen spinal cords were blocked into $8 \mathrm{~mm}$ segments centered on the impact site and then were embedded in Tissue-Tek optimum cutting temperature medium (VWR International). Serial cross-sections $(10 \mu \mathrm{m})$ were cut through each block using a Microm cryostat (HM 505 E), collected on SuperFrost Plus slides (Thermo Fisher Scientific), and stored at $-20^{\circ} \mathrm{C}$.

Injured and naive mice for Real Time qRT-PCR analyses were transcardially perfused at 7 or $21 \mathrm{dpi}(n=3$ per group) with DEPC PBS, and $5 \mathrm{~mm}$ of tissue centered on the injury site was rapidly dissected, snap frozen in liquid nitrogen, and stored at $-80^{\circ} \mathrm{C}$ until processed for cDNA.

An additional set of mice was used for spinal cord Epon embedding. Naive or mice injured as above were perfused with PBS, followed by $4 \%$ $\mathrm{PFA} / 2 \%$ glutaraldehyde solution at 21 or $42 \mathrm{dpi}(n=3-4$ per group). Spinal cords were removed, and a $2 \mathrm{~mm}$ segment of tissue centered on the lesion epicenter was blocked, which was then bisected to produce two 1 $\mathrm{mm}$ blocks of tissue containing the rostral and caudal portions of the lesion. Tissue was processed for Epon embedding and semithin sections cut at $1 \mu \mathrm{m}$ in a transverse orientation on an ultramicrotome (Ultracut MZ6; Leica). Sections were stained with $1 \%$ toluidine blue, dehydrated through increasing ethanol, and coverslipped. 
Table 1. Primer sequences for real-time RT-PCR

\begin{tabular}{lll}
\hline Mus gene & Forward primer $\left(5^{\prime}\right.$-3 $\left.^{\prime}\right)$ & Reverse primer $\left(5^{\prime}\right.$ - $\left.^{\prime}\right)$ \\
\hline 18S & TTCGGAACTGAGGCCATGAT & TTTCGCTCTGGTCCGTCTTG \\
BMP2 & CGTGCGCAGCTTCCATCACG & GAAGAAGCGCGGGCCGTTT \\
BMP4 & GCATCCGAGTGAGAGACCCCA & ATCCCATCAGGGACGAGACCA \\
FGF2 & GGCTGCTGGCTTCTAAGTGT & ACTGGAGTATTTCGTGACCG \\
ID2 & GCTCTACAACATGAACGACTGCTACT & TGCAGGTCCAAGATGTAATCGA \\
ID4 & GAGACTCACCCTGCTTTGCT & AGAATGCTGTCACCCTGCTT \\
IGF-1 & TGACATGCCCAAGACTCAGAAG & GCGGTGATGTGGCATTTCC \\
IL-1 $\beta$ & CAGGCTCCGAGATGACAAC & GGTGGAGAGCTTTCAGCTCATAT \\
PDGF-A & ACCCCACATCGGCCAACT & CCGTGAAGGCTGGCACTT \\
TGF $\beta$ & TGAGTGGCTGTCTTTTGACGTC & TTCATGTCATGGATGGTGCC \\
\hline
\end{tabular}

$q R T-P C R$. Frozen spinal cord segments were suspended in $1 \mathrm{ml}$ of ice-cold TRIzol (Invitrogen) and homogenized with a tissue grinder. Gene-specific primer pairs (Table 1) were used to detect mRNA expression in uninjured and SCI samples by qRT-PCR. Primer sequence specificity was confirmed by BLAST analysis for highly similar sequences against known sequence databases. Briefly, total RNA was purified using TRIzol (Invitrogen) and quantified by spectrophotometry. cDNA was prepared from RNA by RT with SuperScript II and random primers (Invitrogen). PCR reactions were performed using $10 \mathrm{ng}$ of cDNA, 500 nM each primer, and SYBR Green master mix (Applied Biosystems) in 10 $\mu \mathrm{l}$ reactions. Levels of PCR product were measured using SYBR Green fluorescence collected on a 7900HT Real-Time PCR System (Applied Biosystems). Standard curves were generated for each gene using a control cDNA dilution series. Melting point analyses were performed for each reaction to confirm single amplified products. Data are calculated using the $\Delta \Delta$ Ct method (Schmittgen and Livak, 2008) and expressed as fold change from uninjured spinal cord samples (gene/18S ratio for uninjured samples equals one). Forward and reverse primer sequences for each gene are listed in Table 1.

Immunohistochemistry. For tissue analysis, the following targets were visualized using immunohistochemistry: OPCs (rabbit anti-NG2, 1: 600, catalog \#C5067-70D; US Biological), OLs (rabbit anti-GST $\pi$, 1:2000, catalog \#Orb18037; Biorbyt), ferritin (rabbit anti-H-ferritin, $1: 10,000$, catalog \#65080; Abcam; plus rabbit anti-L-ferritin, 1:2000, catalog \#69090; Abcam), macrophages [rat anti-cluster of differentiation (CD) 68, 1:1000, catalog \#MCA1957; Serotec and rat anti-CD11b, 1:800, catalog \#MCA-74G; Serotec], proliferating cells (biotinylated sheep antiBrdU, 1:200, catalog \# ab2284). Sections were rinsed in $0.1 \mathrm{M}$ PBS and blocked for nonspecific antigen binding using 4\% BSA/0.1\% Triton $\mathrm{X}-100 / \mathrm{PBS}\left(\mathrm{BP}^{+}\right)$for $1 \mathrm{~h}$. Next, sections were incubated in primary antibody overnight at $4^{\circ} \mathrm{C}$. Sections were rinsed and treated with rat or rabbit biotinylated antiserum (rabbit anti-rat IgG at 1:800 or goat antirabbit IgG at 1:2000 in $\mathrm{BP}^{+}$; Vector Laboratories) for $1 \mathrm{~h}$ at room temperature. After rinsing, endogenous peroxidase activity was quenched using a 4:1 solution of methanol/30\% hydrogen peroxide for $15 \mathrm{~min}$ in the dark. Sections were treated with Elite avidin-biotin enzyme complex (ABC; Vector Laboratories) for $1 \mathrm{~h}$. Visualization of labeling was achieved using DAB substrates (Vector Laboratories). Sections were rinsed, dehydrated, and coverslipped with Permount (Thermo Fisher Scientific). For GST $\pi$ (DAB) immunohistochemistry, sections underwent antigen retrieval using high $\mathrm{pH}$. For GST $\pi /$ TUNEL immunofluorescence, sections were immunolabeled for GST $\pi$ (1:200, with goat anti-rabbit 546 at 1:500), followed by TUNEL staining according to the instructions of the manufacturer (catalog \#4810-30-K; Trevigen) tagged with Streptavidin 488 (1:500; Invitrogen). For GST $\pi /$ BrdU immunohistochemistry, sections were immunolabeled for GST $\pi$ (1:200, with goat anti-rabbit 546 at 1:500), treated with $2 \mathrm{~N} \mathrm{HCl}$ at $37^{\circ} \mathrm{C}$ for $25 \mathrm{~min}$ to denature DNA before primary antibody incubation, and then tagged with Streptavidin 488 (1:500; Invitrogen). Sections labeled with GST $\pi$ antibodies (DAB) to identify OLs were counterstained with methyl green. Sections labeled with NG2 antibody were counterstained with neutral red. Endogenous peroxidase activity was used to visualize red blood cells (RBCs) through reaction with DAB (Vector Laboratories) without previous treatment with hydrogen peroxide or $\mathrm{ABC}$ solution.
Tissue staining. Eriochrome cyanine (EC) labeling of myelin was used to determine the lesion epicenter (cross-section with least amount of spared white matter).

Oil Red O stain was used to measure lipid accumulation. Sections were rinsed in $\mathrm{dH}_{2} \mathrm{O}$ and $70 \%$ ethanol each for 2 min before being placed in a saturated solution of Oil Red O (catalog \# O0625-25G; Sigma-Aldrich) dissolved in $70 \%$ ethanol at $60^{\circ} \mathrm{C}$ for $30 \mathrm{~min}$. The tissue was differentiated in ethanol, washed in distilled water, and then coverslipped with Immumount (Thermo Fisher Scientific).

Perls Prussian Blue stain (catalog \#24199-1; Polysciences) was used to visualize iron. Tissue sections were rinsed in $0.1 \mathrm{M}$ PBS and $0.1 \%$ Triton $\mathrm{X}-100 / \mathrm{PBS}$ for $10 \mathrm{~min}$ each, followed by incubation in a 1:1 mixture of $\mathrm{HCl}$ plus potassium ferrocyanide solution for $30 \mathrm{~min}$ and $\mathrm{DAB}$ plus nickel intensification (Vector Laboratories). Sections were rinsed, dehydrated, and coverslipped with Permount (Thermo Fisher Scientific).

Proportional area analysis. To quantify NG2, Perls, DAB, CD11b, and CD68 immunoreactivity, low power $(5 \times)$ images located $0.6 \mathrm{~mm}$ rostral or caudal to the lesion epicenter were digitized and manually outlined using image analysis software (MCID Elite; Imaging Research). The proportion of the cross-section occupied by positive immunoreactivity was calculated by dividing the area immunoreactive by the total crosssectional area.

Intraspinal lipid accumulation was analyzed using the proportional area of Oil Red O staining normalized to the lesion scan area outlined using $\mathrm{EC} /$ neurofilament staining. The trace of the core lesion area outlined at low power $(4 \times)$ was overlaid on Oil Red O-stained cross-sections, and positive staining was analyzed within that area. Proportional area analysis of $\mathrm{H}$ - and L-ferritin was conducted in the same way.

Axon counts. Axons were counted in Epon-embedded sections stained with $1 \%$ toluidine blue. Two representative images per animal were taken at $100 \times$ magnification $\left(5951 \mu \mathrm{m}^{2}\right)$ in the ventromedial white matter 0.5 $\mathrm{mm}$ caudal to the lesion epicenter (AxioVision; Zeiss). All visible axons within the sampled area were counted. Counts from both images were averaged to obtain one value per animal.

Cell density quantification. OLs (GST $\pi^{+}$cells) were counted in tissue cross-sections at $5 \times$ using image analysis software (MCID Elite; Imaging Research). First, the average positive cell size was determined, and manual immunoreactivity thresholding was used to detect and automatically count all positively labeled cells in the sample area. Naive or epicenter sections were analyzed at $1 \mathrm{dpi}$, and sections $0.6 \mathrm{~mm}$ rostral and caudal to the epicenter were analyzed at $1,7,14$, and 21 dpi.

Cells immunoreactive for NG2 in the epicenter at 1 dpi were manually counted at $40 \times$. The criteria to count a cell included each profile having a well defined border surrounding an identifiable nucleus. A cell was only counted if both criteria were met in the same plane of focus. Cell type was verified at higher power $(64 \times)$ when needed. $\mathrm{NG}^{+}$macrophages or pericytes were excluded based on morphological criteria (McTigue et al., 2001).

Cells immunofluorescent for both GST $\pi /$ TUNEL or GST $\pi / \mathrm{BrdU}$ were counted at $20 \times$ with $3 \times$ zoom using confocal microscopy $(510$ META laser scanning confocal microscope; Zeiss) in optical sections $(\sim 1 \mu \mathrm{m})$. Bilateral sample boxes $\left(0.0441 \mathrm{~mm}^{2}\right)$ were placed in the ventromedial white matter $0.6 \mathrm{~mm}$ rostral and caudal to the lesion epicenter. All cell count data are expressed as cells per cubic millimeter.

Bone marrow-derived macrophage cell culture. Bone marrowderived macrophage (BMDM) cultures were generated as described previously (Longbrake et al., 2007) from adult male C3H/HeJ and $\mathrm{C} 3 \mathrm{H} / \mathrm{HeOuJ}$ mice (The Jackson Laboratory). Briefly, BMDMs were obtained from bilateral femurs and tibias using aseptic techniques. Marrow cores were flushed into sterile tubes using syringes fit with 26 gauge needles and filled with DMEM/10\% FBS. Cells were triturated three to five times, and RBCs were lysed in lysis buffer $\left(0.15 \mathrm{M} \mathrm{NH}_{4} \mathrm{Cl}\right.$, $10 \mathrm{mM} \mathrm{KHCO}_{3}$, and $0.1 \mathrm{~mm} \mathrm{Na}_{2}$ EDTA, pH 7.4). Cells were washed once in media and then plated and cultured in DMEM supplemented with $0.5 \%$ gentamicin, $1 \%$ glutaMAX, $1 \%$ HEPES, $0.001 \%$ $\beta$-mercaptoethanol, 10\% FBS, and 20\% supernatant from sL929 cells. The sL929 (which contains macrophage colony-stimulating factor) is needed to promote differentiation of bone marrow cells into macro- 
phages (7-10 d; Burgess et al., 1985). Cells were replated at 5000 cells per well on day 7 in DMEM supplemented with $10 \%$ FBS, $1 \%$ glutaMAX, and $0.5 \%$ gentamicin. Cells were treated with pHrodo Redlabeled myelin at $1 \mu \mathrm{g}$ per 80,000 cells (see below) and replating media or LPS $(0.1 \mu \mathrm{g} / \mathrm{ml}$; Sigma-Aldrich $)$ made in replating media for $24 \mathrm{~h}$. All treatment groups were run in triplicate.

Myelin isolation and $p H r o d o$ Red dye labeling. Myelin from the brain of an adult male $\mathrm{C} 3 \mathrm{H} / \mathrm{HeOuJ}$ (WT) mouse was isolated using a modified version of the methods outlined previously (Hendrickx et al., 2014). The whole brain was mechanically dissociated through a 70 $\mu \mathrm{m}$ mesh filter using cold $0.1 \mathrm{M}$ PBS, followed by density gradient separation using Percoll (catalog \#GE17-0891-01; Sigma) of 70, 35, and $0 \%$ Percoll in PBS. Myelin was collected from the $0-35 \%$ interface, resuspended in $0.32 \mathrm{~m}$ sucrose, and further purified using a sucrose gradient (Norton and Poduslo, 1973) of $0.85,0.32$, and $0 \mathrm{M}$ sucrose. Liquid was aspirated, and myelin was washed in $\mathrm{dH}_{2} \mathrm{O}$ and suspended in 0.1 M PBS, pH 7.4.

Myelin concentration was measured using the Pierce BCA protein assay kit (catalog \#23225; Thermo Fisher Scientific) and labeled with pH-sensitive dye pHrodo Red, succinimidyl ester (catalog \#P36600; Thermo Fisher Scientific) dissolved in DMSO. Myelin was suspended in $0.1 \mathrm{M}$ PBS, $\mathrm{pH} 8.4$, and incubated with $0.1 \mathrm{~mm}$ dye at room temperature for $45 \mathrm{~min}$. Myelin ${ }^{+}$dye was spun and resuspended in $0.1 \mathrm{M}$ PBS, pH 7.4, and stored at $-80^{\circ} \mathrm{C}$ until used.

Phalloidin immunofluorescence. BMDM morphology was visualized using phalloidin staining with Hoechst nuclear stain. Fixed cells were washed in 5\% FBS/PBS, permeabilized with $0.2 \%$ Triton X-100, and incubated with Alexa Fluor Phalloidin 488 (1:1000, catalog \#A12379; Thermo Fisher Scientific) for $3 \mathrm{~h}$ at room temperature. Cells were washed and treated with Hoechst $(1: 50,000)$ for 5 min and left in PBS.

Myelin phagocytosis analysis of BMDMs. Cells were identified as BMDMs if they were Hoechst ${ }^{+}$and phalloidin ${ }^{+}$. Phalloidin ${ }^{+}$BMDMs were determined by thresholding against the background intensity in nonstained wells. The average phalloidin intensity was at least three times the background intensity. Hoechst ${ }^{+}$cells that were phalloidin negative were excluded from analysis. BMDM myelin uptake was determined by thresholding the myelin intensity against the background intensity in non-treated BMDM wells. A BMDM that had taken up myelin was at least three times the maximum background intensity in the nontreated wells. The presence of myelin was quantified using the ArrayScanXTI Spot Detector Algorithm (Thermo Fisher Scientific). Two hundred fifty Hoechst/phalloidin ${ }^{+}$cells were analyzed per well for their myelin content. The proportion of cells containing myelin was determined for WT and TLR4d-derived BMDMs that received either media or LPS $(0.1 \mu \mathrm{g} / \mathrm{ml})$ treatment. The fold change was determined by comparing the proportion of myelin ${ }^{+}$BMDMs in each condition to the proportion in the media-treated wells. Three wells per treatment were analyzed and averaged.

Data analysis. All data were collected in a blinded manner. Data were analyzed using GraphPad Prism 5.0c and are presented as mean \pm SEM. Behavioral data and GSTpi/BrdU counts at 14 dpi were analyzed by two-way repeated-measures ANOVA with Bonferroni's post hoc test. Ferritin, Perls and DAB proportional area, OL counts, and NG2 cell counts at 1 dpi were analyzed by Student's two-tailed $t$ test. OL counts over time, NG2 proportional area, and Oil Red O proportional area were analyzed by two-way ANOVA at each distance with Bonferroni's post hoc test. All other data (including cell culture) were analyzed by two-way ANOVA with Bonferroni's post hoc test.

\section{Results}

\section{Functional recovery is reduced in TLR4d mice after SCI}

Previous data from our group showed that, after SCI, female TLR4d $(\mathrm{C} 3 \mathrm{H} / \mathrm{HeJ})$ and WT $(\mathrm{C} 3 \mathrm{H} / \mathrm{HeOuJ})$ mice had similar degrees of gross hindlimb locomotor recovery; however, female TLR4d mice displayed significant deficits in fine details of locomotion, most notably interlimb coordination (Kigerl et al., 2007). Here, male TLR4d mice were used to evaluate recovery after SCI. Both genotypes had normal locomotion before SCI. At

\section{A Open Field Locomotion}
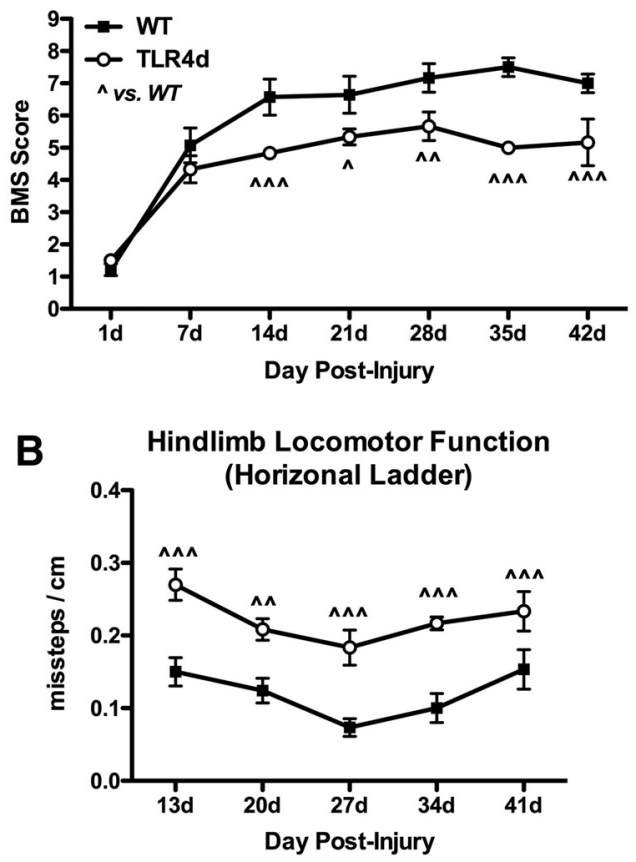

Figure 1. TLR4d mice displayed significantly worse hindlimb recovery after moderate $\mathrm{SCl}$. $\boldsymbol{A}$ Open-field locomotion was analyzed by two investigators in a blinded manner using the BMS. This revealed that WT and TLR4d mice displayed significant hindlimb paralysis at $1 \mathrm{dpi}$, followed by recovery plantar stepping by $7 \mathrm{dpi}$. At $14 \mathrm{dpi}$, the locomotor function of WT mice was significantly greater than in TLR4d mice, which was maintained through 42 dpi. $\boldsymbol{B}$, Automated horizontal ladder analysis beginning once stepping was regained confirmed that TLR4d mice displayed worse hindlimb function compared with WT. $\wedge p<0.05, \wedge \wedge p<0.01, \wedge \wedge \wedge p<$ .001 vs WT. Data are mean \pm SEM.

$1 \mathrm{dpi}$, all mice displayed significant hindlimb paralysis (BMS score $<2$ ) and then recovered the ability to plantar step over the first 7 dpi (score $\geq 4$; Fig. 1A). WT mice progressed to coordinated and consistent plantar stepping by $14 \mathrm{dpi}$ (mean score of 6.6), whereas TLR4d mice failed to achieve forelimb-hindlimb coordination, and BMS scores remained significantly impaired through 42 dpi (mean score of $4.8 ; p=0.0001$ ).

Once mice regained plantar stepping, locomotor ability was tested using the automated horizontal ladder test (Fig. 1B). Although both genotypes navigated the ladder with few errors before SCI, TLR4d mice had significantly more missteps after SCI than WT mice $(p<0.0001)$. WT mice walked steadily across the ladder, whereas TLR4d mice were shaky, slow, and relied on the apparatus walls for support. These data confirm that TLR4 signaling is important for spontaneous recovery of locomotion after SCI, especially more advanced recovery milestones such as coordination, paw position, and balance.

\section{Acute OL and NG2 cell loss is exacerbated after SCI in TLR4d mice}

Our previous work showed that mice deficient in TLR4 signaling have significantly less white matter sparing after SCI (Kigerl et al., 2007). Because previous work also linked TLR4 signaling and OL replacement (Schonberg et al., 2007), we hypothesized that TLR4d spinal cords would have greater OL lineage cell loss and/or impaired OL replacement. Thus, OLs and $\mathrm{NG}^{+}$cells (putative OL progenitors) were quantified in WT and TLR4d epicenters at $1 \mathrm{dpi}$. Significant OL and NG2 cell loss occurred in both genotypes; however, TLR4d mice had a greater loss of OLs 

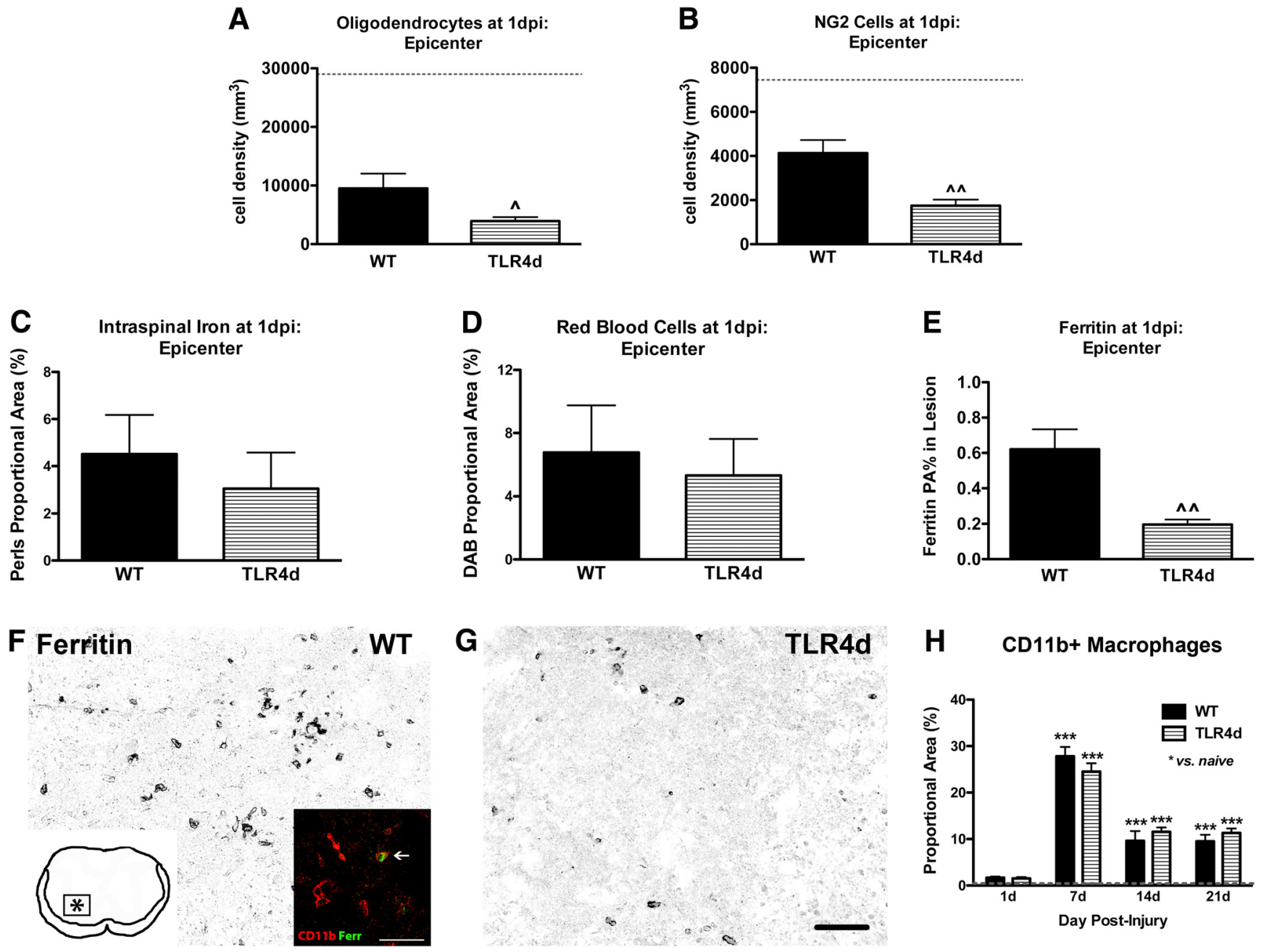

Figure 2. OL lineage cell sparing is reduced concurrent with less ferritin in TLR4d mice after SCI. GST $\pi^{+}$OLs $(\boldsymbol{A})$ and NG2 ${ }^{+}$cells $(B)$ were significantly reduced at 1 dpi in the lesion epicenter compared with naive (---). TLR4d tissue had significantly fewer OLs and NG2 ${ }^{+}$cells compared with WT. C, $\boldsymbol{D}$, Both genotypes show comparable levels of intraspinal iron and RBCs in the lesion epicenter at 1 dpi. $\boldsymbol{E}$, Proportional area of immunoreactivity for the iron storage molecule ferritin is reduced in TLR4d mice at $1 \mathrm{dpi} \mathrm{in} \mathrm{the} \mathrm{lesion} \mathrm{epicenter.} \boldsymbol{F}, \boldsymbol{G}$, Representative images of WT and TLR4d ferritin labeling in epicenter lesions $1 \mathrm{dpi}$. Map in $\boldsymbol{F}$ shows region of image collection. Inset shows confocal image of macrophages (CD11b, red), one of which expresses ferritin (green, arrow). $\boldsymbol{H}$, Proportional area of CD11b immunoreactivity in the epicenter after $S C l . A, B,---$ indicates naive level. Scale bars: $\boldsymbol{F}, \boldsymbol{G}, 100 \mu \mathrm{m}$; inset, $25 \mu \mathrm{m}$. ${ }^{* * *} p<0.001$ vs naive; $\wedge p<0.05$ and $\wedge \wedge p<0.01$ versus WT. Data are mean \pm SEM.

$(p<0.05)$ and NG2 cells $(p<0.01)$ compared with WT mice at 1 dpi (Fig. $2 A, B$ ). These data suggest that TLR4 signaling confers protection for OL lineage cells within the acute SCI lesion environment.

\section{Ferritin expression is reduced in TLR4d lesion epicenters $1 \mathrm{~d}$ after injury}

Iron-mediated damage can contribute to acute glial cell loss after SCI. Intraparenchymal hemorrhage causes iron-rich RBCs to accumulate rapidly within the injured spinal cord (Noble and Wrathall, 1989; Sauerbeck et al., 2013). Macrophages are adept at removing extracellular iron, and TLR4 activation promotes their iron sequestration by stimulating iron uptake and storage in intracellular ferritin (Recalcati et al., 2010; Urrutia et al., 2013). Because iron is toxic to OLs (for review, see McTigue and Tripathi, 2008; Almad et al., 2011), excess iron in TLR4d spinal cords could exacerbate acute postSCI OL loss.

Epicenter sections from TLR4d and WT mice were analyzed at $1 \mathrm{dpi}$, which is the time of peak intraspinal blood and iron accumulation (Sauerbeck et al., 2013). Iron and RBCs were analyzed using Perls stain (non-heme iron) and DAB stain (RBCs). We found comparable levels of intraspinal iron and RBCs in both genotypes (Fig. 2C,D), which indicates that TLR4d and WT mice had similar magnitudes of primary trauma, bleeding, and breakdown of blood-derived hemoglobin. Although ferritin levels increased rapidly in both TLR4d and WT spinal cords (undetectable in naive tissue with immunohistochemistry), ferritin was significantly lower in TLR4d lesion sites ( $p<0.01$ vs WT; Fig. $2 E-G$ ). Our previous work showed that the vast majority of ferritin ${ }^{+}$cells in the SCI lesion site were macrophages (Sauerbeck et al., 2013), which was confirmed here (Fig. $2 F$ ). Therefore, reduced ferritin in TLR4d lesions could indicate an attenuated inflammatory response (i.e., fewer macrophages) or impaired TLR4-mediated ferritin expression by macrophages. To assess this, CD11b immunoreactivity as a function of time after injury was analyzed. There was no difference in the magnitude of the microglia or macrophage response between genotypes over the first week after injury and up to 21 dpi (Fig. $2 H$ ). CD68 immunohistochemistry to label activated microglia/macrophages showed similar results (data not shown). Together, these data 
A
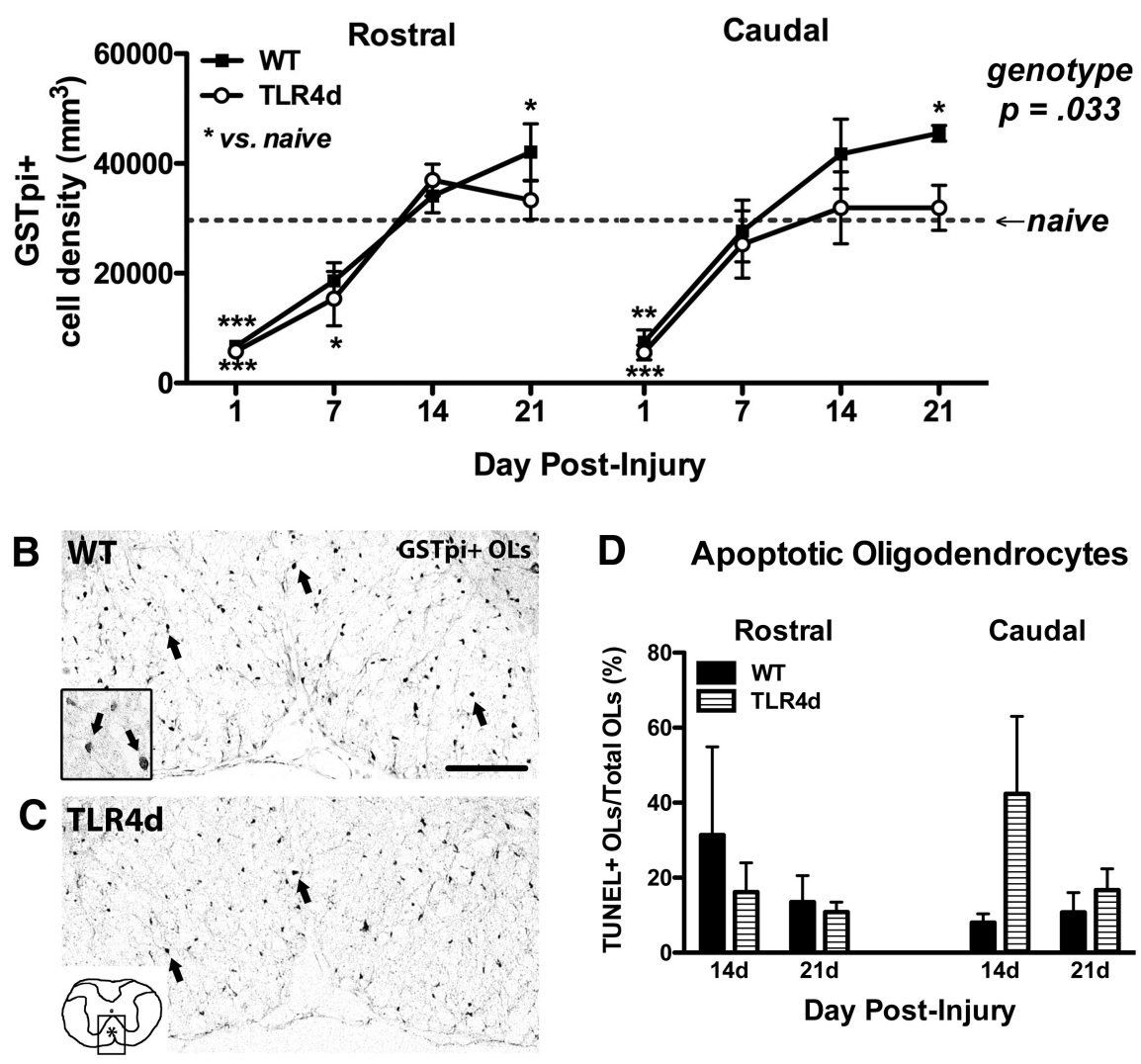

D Apoptotic Oligodendrocytes

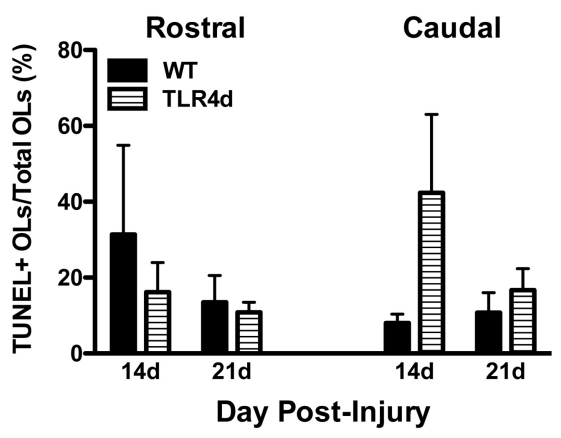

Figure 3. OLs are reduced chronically in TLR4d mice after SCI. $A$, Counts of GST $\pi^{+} \mathrm{OLs}$ at $0.6 \mathrm{~mm}$ rostral and caudal to the lesion epicenter at 1,7,14, and 21 dpi compared with naive (----). B, C, Representative images of GST $\pi^{+}$OLs in the ventral spinal cord $0.6 \mathrm{~mm}$ caudal to the epicenter at $21 \mathrm{dpi}$ in WT and TLR4d mice. Inset shows representative GST $\pi^{+}$cells (arrows). Map in C shows region of image collection for $\boldsymbol{B}$ and $\boldsymbol{C}$. $\boldsymbol{D}$, Percentage of GST $\pi^{+} / \mathrm{TUNEL}^{+}$apoptotic $0 \mathrm{Ls}$ normalized to overall GST $\pi^{+}$OLs in ventromedial white matter at $0.6 \mathrm{~mm}$ rostral and caudal to the lesion epicenter at 14 and $21 \mathrm{dpi}$. Scale bar: $\boldsymbol{B}, \boldsymbol{C}, 100 \mu \mathrm{m} .{ }^{*} p<$ $0.05,{ }^{* *} p<0.01,{ }^{* * *} p<0.001$ versus naive. Data are mean \pm SEM.

indicate that, although the overall number of macrophages is comparable between genotypes, TLR4 deficiency impairs iron sequestration and storage. This is significant because extracellular iron could exacerbate OL (and other cell) loss.

TLR4d mice have reduced OLs chronically after SCI

Previously, we showed that SCI induces robust OL genesis, producing more OLs in spared tissue than in naive, especially in regions distal to the epicenter where chronic remyelination is greatest (Tripathi and McTigue, 2007; Hesp et al., 2015). We also showed that intraspinal TLR4 activation stimulates OL genesis (Schonberg et al., 2007), raising the possibility that TLR4 signaling contributes to spontaneous OL replacement after SCI. Here, we quantified OLs distal to epicenter in TLR4d and WT spinal cords (Fig. $3 A$ ). In both genotypes, OLs were significantly reduced at $1 \mathrm{dpi}$ ( $p<0.001$ vs naive) and increased to naive levels by 7-14 dpi. In WT mice, OL numbers continued to rise through $21 \mathrm{dpi}$, with OL numbers exceeding those in naive tissue $(p<$ $0.05)$. In contrast, OL numbers did not change after 14 dpi in TLR4d tissue, resulting in significantly fewer OLs compared with WT (genotype effect for caudal tissue $p=0.033$; Fig. $3 A-C$ ). Notably, this is also the time when functional recovery diverges between the two genotypes (Fig. 1).
OL apoptosis was not different between WT and TLR4d mice

TLR4 deficiency results in enhanced OL loss acutely after SCI (see above). To determine whether the lack of TLR4 signaling increases chronic OL apoptosis, cross-sections were double-labeled for GST $\pi$ and TUNEL to label apoptotic OLs in sections from 14 and $21 \mathrm{dpi}$, times when post-SCI OL apoptosis in descending tracts is prevalent (Warden et al., 2001). Double-labeled cell counts in ventromedial white matter rostral and caudal to the epicenter revealed comparable numbers of apoptotic OLs at both times in all animals (Fig. 3D). Thus, lower OL numbers in TLR4d tissue was not attributable to significantly enhanced OL apoptosis.

TLR4d mice have reduced axon sparing chronically after SCI

To determine whether fewer OLs in TLR4d mice led to reduced axon myelination chronically, semi-thin Eponembedded sections from uninjured, 21 $\mathrm{dpi}$, and 42 dpi spinal cords were prepared. Given their pivotal role in locomotor function, axons in the caudal ventromedial white matter were examined (Rosenberg and Wrathall, 1997). As expected, naive spinal cords were intact and indistinguishable between genotypes (Fig. $4 A, B$ ). At 21 and $42 \mathrm{dpi}$, few bare axons were present in either genotype, indicating that TLR4 deficiency did not exacerbate demyelination in this white matter region. However, significantly fewer total axons were present in the ventral funiculus in TLR4d mice compared with WT at both time points (Fig. $4 A, B$ ), which likely contributed to the reduced locomotor recovery in the TLR4d group. Tissue disruption was more extensive in TLR4d tissue, including increased pathological axon profiles and more myelin debris, suggesting reduced debris clearance and/or greater active chronic degeneration.

NG2 expression was reduced in TLR4d mice after injury

The fact that chronic OL apoptosis was comparable between genotypes but TLR4d tissue had lower OL numbers 2-3 weeks after injury suggests that fewer new OLs were produced. New OLs arise mainly from NG2 ${ }^{+}$OPCs after spinal contusion. To determine whether TLR4 altered NG2 cells after SCI, NG2 immunoreactivity was analyzed $0.6 \mathrm{~mm}$ rostral and caudal to the epicenter. These are the same distances at which OL numbers were quantified (Fig. 3) and are known regions of NG2 cell proliferation after SCI (McTigue et al., 2006; Tripathi and McTigue, 2007). Because counting individual NG2 cells was not feasible due to dense NG2 accumulation along the lesion and adjacent spared tissue (Fig. 5A-D), the overall area of NG2 immunoreactivity was quantified. Rostrally, NG2 immunoreactivity robustly increased in both genotypes by $7 \mathrm{dpi}$ and then declined slightly by $14 \mathrm{dpi}$, after which it stabilized in WT 
tissue ( $p<0.001$ vs naive). This decline in NG2 continued in the TLR4d cords and became significantly reduced by 21 dpi $(p<0.05$; Fig. 5E).

Caudally, NG2 immunoreactivity increased in both groups by $7 \mathrm{dpi}(p<0.001$ vs naive). However, the NG2 cell response was muted in TLR4d cords and was significantly lower than WT at 7-21 dpi $(p<$ 0.0001 ; Fig. $5 E$ ). These results are consistent with the OL number changes, which showed a more drastic deficit caudal to the epicenter.

In addition to an overall reduction in $\mathrm{NG} 2$, the morphology of $\mathrm{NG}_{2}{ }^{+}$profiles differed between TLR4d and WT spinal cords. In WT, $\mathrm{NG}^{+}$cells formed thick interwoven processes along and within the lesion border (Fig. $5 A, C$ ). In contrast, in TLR4d spinal cords, $\mathrm{NG}^{+}$cells and processes were shorter and did not form a boundary or scar (Fig. $5 B, D$ ), similar to what Kigerl et al. (2007) noted for astrocytes after SCI in TLR4d mice.

TLR4 deficiency impairs differentiation into OLs of acutely proliferating

OL progenitors

$\mathrm{NG}_{2}{ }^{+} \mathrm{OL}$ progenitors divide during the first week after SCI, and a portion differentiate into new OLs. To determine whether the generation of new OLs was affected by TLR4 deficiency, mice were injected with BrdU from 1 to 7 dpi to label dividing OPCs, and the tissue was examined at 14pi for the percentage of new OLs $\left(\mathrm{BrdU}^{+} / \mathrm{GST}^{+}\right)$. This analysis revealed a significant effect of distance (rostral vs caudal, $p=0.0456$ ) and significant interaction between genotype and distance $(p=$ 0.0371; Table 2).

In rostral WT sections, $\sim 48 \%$ of OLs were $\mathrm{BrdU}^{+}$, indicating that they were formed after SCI from OPCs dividing during the first $7 \mathrm{dpi}$ (Table 2). In contrast, the percentage of new OLs in TLR4d sections was half that of WT $(\sim 24 \%)$. Caudal to the epicenter, WT mice had a trend for a greater percentage of new OLs compared with TLR4d ( $\sim 24$ vs $\sim 17 \%$; Table 2$)$. These data indicate that TLR4 signaling contributes to the post-SCI differentiation of proliferating OPCs into OLs.

\section{TLR4d mice had reduced lipid debris clearance after SCI}

To gain insight into possible mechanisms contributing to reduced NG2 and OLs in injured TLR4d spinal cords, several parameters were examined. First was myelin debris clearance because myelin debris potently inhibits OL differentiation (Robinson and Miller, 1999; Kotter et al., 2006; Plemel et al., 2013), and TLR4 activation facilitates phagocyte recruitment and myelin debris clearance after SCI and peripheral nerve injury (Vallières et al., 2006; Boivin et al., 2007; Wu et al., 2013; Li et al., 2014; Rajbhandari et al., 2014). To visualize myelin debris within phagocytes, sections were stained with Oil Red O (Fig. 6A,B). From 7 to 21 dpi, TLR4d mice had significantly less phagocytosed myelin debris in the epicenter $(p=0.006)$ and caudal to the lesion epicenter ( $p=0.0359$; Fig. $6 C$ ). Because the number of macrophages was comparable between genotypes (see above), these results suggest that macrophage lipid phagocytosis was impaired by the lack of TLR4 signaling.

To confirm this finding, we used BMDMs from TLR4d and WT mice in an in vitro myelin phagocytosis assay. BMDMs were treated for $24 \mathrm{~h}$ with media alone or LPS (a TLR4 agonist) and pHrodo Red-labeled WT myelin, which fluoresces red in acidic environments, such as inside a phagosome. TLR4 activation of WT BMDMs doubled the number of cells phagocytosing myelin compared with baseline ( $p<0.01$ vs media; Fig. $6 D, F)$. In contrast, myelin debris phagocytosis by TLR4d BMDMs was unchanged by LPS treatment ( $p<0.05$ vs WT; Fig. $6 E, F)$. This confirms that TLR4 signaling stimulates macrophage myelin debris phagocytosis and that lack of this pathway in vivo likely hampered myelin debris clearance in response to endogenous TLR4 ligands.

Post-SCI expression of growth factors and cytokines related to OL genesis are altered in TLR4d mice

Many growth factors and cytokines with potent effects on OL lineage cells are altered in the SCI environment. Thus, real-time RT-PCR was used to determine whether impaired TLR4 signaling altered expression of factors that influence the proliferation and differentiation of OL lineage cells and subsequent myelination (for review, see McMorris and McKinnon, 1996; Rosenberg et al., 2007). 


\section{WT}
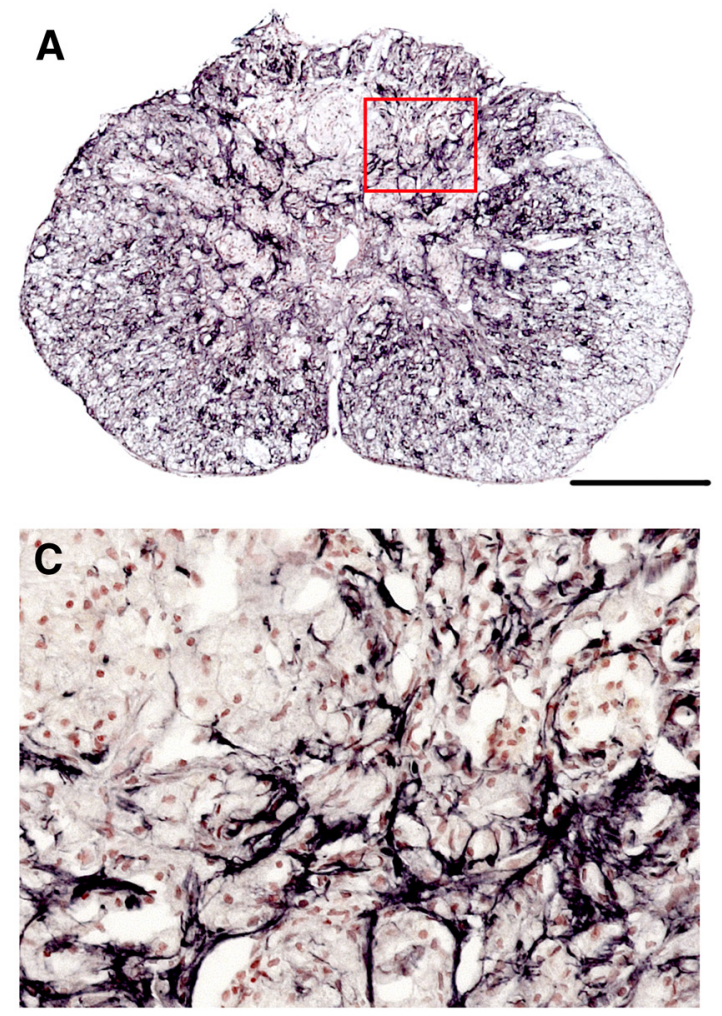

E
Rostral

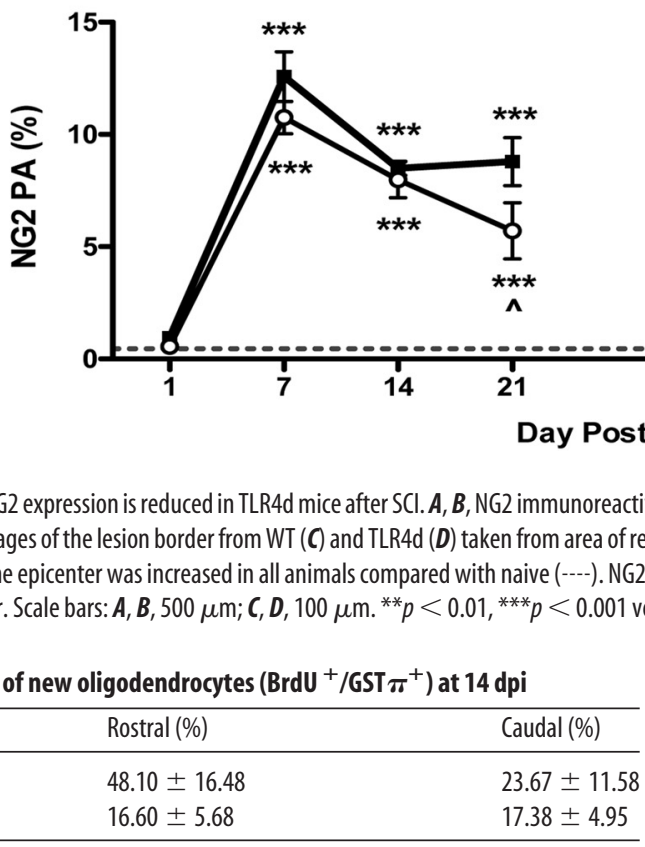
1990) or in combination with insulin-like growth factor-1 (IGF-1; Jiang et al., 2001; Frederick and Wood, 2004; Frederick et al., 2007) can maintain OPCs in a progenitor state and prevent
TLR4 deficiency impairs differentiation into $0 \mathrm{Ls}$ of acutely proliferating $0 \mathrm{~L}$ progenitors. The percentage of new $0 \mathrm{Ls}$ $\left(\mathrm{BrdU} \mathrm{U}^{+} / \mathrm{GST} \pi^{+}\right)$at $14 \mathrm{dpi} 0.6 \mathrm{~mm}$ rostral and caudal to the lesion epicenter was quantified in animals receiving BrdU 1-7 dpi. This analysis revealed a significant effect of distance (rostral vs caudal, $p=0.0456$ ) and a significant interaction between genotype and distance $(p=0.0371)$. Data are mean \pm SEM.

Fibroblast growth factor 2 (FGF2) alone (McKinnon et al.,

Table 2. Percentage of new oligodendrocytes (BrdU ${ }^{+} / \mathrm{GST} \pi^{+}$) at $14 \mathrm{dpi}$

\begin{tabular}{lcl}
\hline & Rostral (\%) & Caudal (\%) \\
\hline WT & $48.10 \pm 16.48$ & $23.67 \pm 11.58$ \\
TLR4d & $16.60 \pm 5.68$ & $17.38 \pm 4.95$ \\
\hline TLR4 deficiency impairs differentiation into 0Ls of acutely proliferating 0 L progenitors. The percentage of new 0Ls \\
$\left(\right.$ BrdU ${ }^{+} /$GST $\pi^{+}$) at 14 dpi 0.6 mm rostral and caudal to the lesion epicenter was quantified in animals receiving \\
BrdU 1-7 dpi. This analysis revealed a significant effect of distance (rostral vs caudal, $p=0.0456)$ and a significant \\
interaction between genotype and distance $(p=0.0371)$. Data are mean \pm SEM.
\end{tabular}

TLR4d
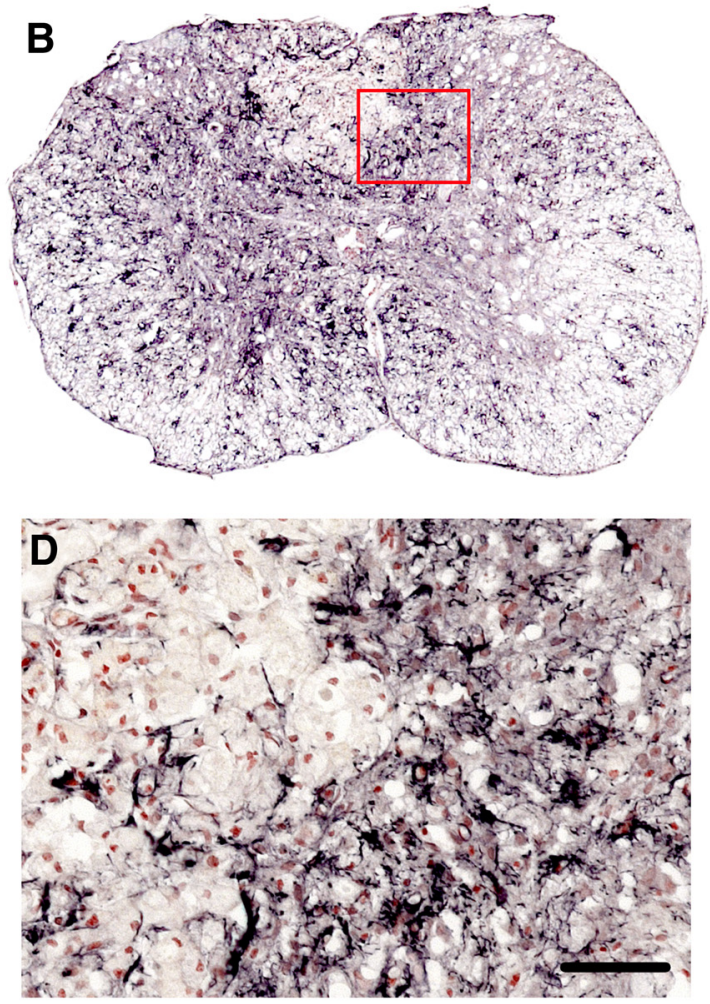

Caudal

Figure 5. Overall NG2 expression is reduced in TLR4d mice after SCI. $A, B, N G 2$ immunoreactivity increased after $S C l$ at $0.6 \mathrm{~mm}$ caudal to the lesion epicenter at $21 \mathrm{dpi}$ in both WT and TLR4d mice. $\boldsymbol{C}, \boldsymbol{D}$, Higher-power images of the lesion border from WT ( $\boldsymbol{C}$ and TLR4d (D) taken from area of red boxes in $\boldsymbol{A}$ and $\boldsymbol{B}$ illustrate differences in NG2 cell morphology. $\boldsymbol{E}$, NG2 immunoreactivity at $0.6 \mathrm{~mm}$ (---). NG2 reactivity in TLR4d mice compared with WT was significantly reduced at $21 \mathrm{dpi} \mathrm{rostral} \mathrm{and} \mathrm{7-21} \mathrm{dpi}$

their differentiation. At $7 \mathrm{dpi}$, TLR4d tissue had significantly greater IGF-1 and FGF2 mRNA compared with WT and naive tissue (Fig. $7 A, B$ ). At 21 dpi, IGF-1 mRNA was significantly increased in TLR4d spinal cords compared with WT and naive (Fig. 7A), whereas FGF2 mRNA had increased in both genotypes (Fig. 7B). Platelet-derived growth factor-A (PDGF-A), a growth factor that promotes OPC survival and proliferation, increased significantly in WT at $21 \mathrm{dpi}(p<0.05)$ but not TLR4d mice (Fig. 7C).

Given the potent actions of TLR4 signaling on cytokine expression, levelsof the proinflammatory cytokine interleukin-1 $\beta$ (IL$1 \beta$ ) was examined, because it is necessary for OL remyelination in mice (Mason et al., 2001) and was noted previously to be lower in TLR4d SCI mice at 3 and 7 dpi (Kigerl et al., 2007). Here, IL-1 $\beta$ RNA 

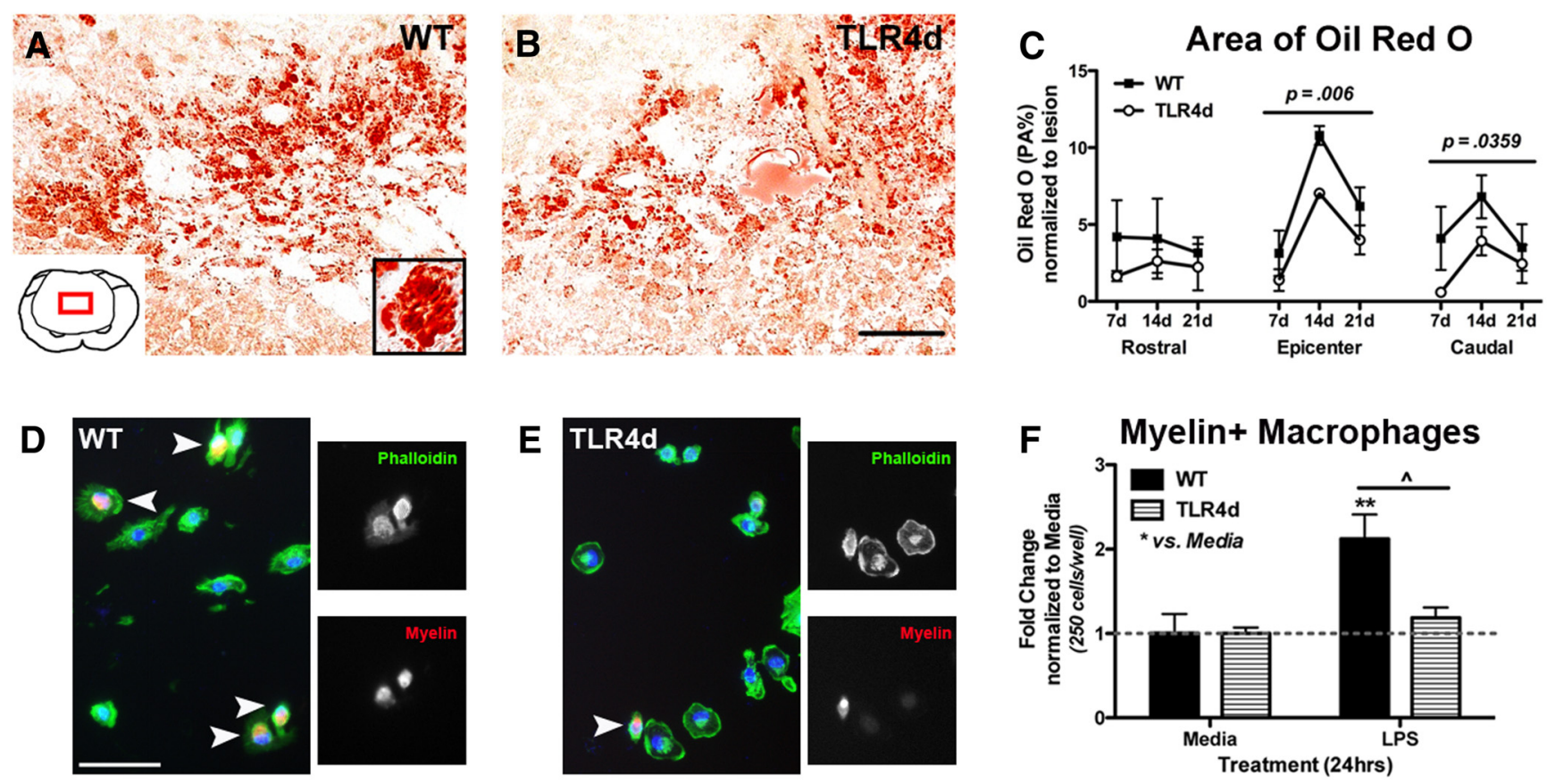

Figure 6. Intraspinal lipid debris is increased in TLR4d mice after $S C I . A, B$, High-power representative images of Oil Red 0 stain $0.6 \mathrm{~mm}$ caudal to thelesion epicenter at 7 dpi demonstrate increased lipid debris phagocytosis in WT $(\boldsymbol{A})$ versus TLR4d $(\boldsymbol{B})$ mice. Map in $\boldsymbol{A}$ shows the region of image collection for $\boldsymbol{A}$ and $\boldsymbol{B}$. $\boldsymbol{A}$, Inset, DIC image of phagocytic cell containing lipid debris. $\boldsymbol{C}$, Quantification of the proportional area of Oil Red 0 stain normalized to lesion size at 7, 14 , and 21 dpi at the epicenter and $0.6 \mathrm{~mm}$ rostral and caudal. $\boldsymbol{D}$, $\boldsymbol{E}$, High-power representative images of WT (D) and TLR4d (E) phalloidin ${ }^{+}$BMDMs containing myelin (arrowheads) $24 \mathrm{~h}$ after treatment with LPS. Cells in the bottom portion indicated by arrowheads are shown as phalloidin and myelin single channels on the right. $F$, Quantification of myelin containing BMDMs treated with pHrodo Red tagged WT myelin and media or LPS for $24 \mathrm{~h}$ in vitro. $\wedge p<0.05,{ }^{* *} p<0.001$. Scale bars: $\boldsymbol{A}, \boldsymbol{B}, 100 \mu \mathrm{m} ; \boldsymbol{D}, \boldsymbol{E}, 50 \mu \mathrm{m}$. Data are mean \pm SEM.

levels were similar at $7 \mathrm{dpi}$ and elevated in WT at $21 \mathrm{dpi}$ ( $p<0.001$ vs naive) but not in TLR4d mice ( $p<0.01$ vs WT; Fig. $7 D)$. This reveals that TLR4 signaling is likely required for chronic IL-1 $\beta$ expression after SCI.

Inhibitors of OL differentiation are elevated in TLR4d mice after SCI

Another family of molecules that regulate glial responses are the bone morphogenetic proteins (BMPs), part of the transforming growth factor- $\beta$ (TGF $\beta$ ) superfamily. BMPs rise over time after SCI (Chen et al., 2005; Hampton et al., 2007; Sahni et al., 2010; Hesp et al., 2015) and are affected by TLR signaling and nuclear factor $-\kappa \mathrm{B}$ activation (Huang et al., 2014; Yang et al., 2014). Therefore, mRNA for BMP2, BMP4, and TGF $\beta$ were compared in TLR4d and WT SCI sites.

BMP2 RNA showed no significant difference in either genotype (data not shown). At 7 dpi, BMP4 mRNA had doubled in TLR4d tissue but was unchanged in WT (Fig. 8A). By 21 dpi, BMP4 mRNA in WT tissue was variable and had risen on average 2.5 times over naive; in TLR4d tissue, BMP4 mRNA was three times higher than naive $(p<$ 0.05 vs naive). TGF $\beta$ mRNA was twofold lower in TLR4d tissue at 7 dpi but was significantly increased more than fourfold at $21 \mathrm{dpi}$ in TLR4d compared with WT tissue and naive $(p<0.001$ vs WT and naive; Fig. $8 B$ ).
A

IGF1 mRNA

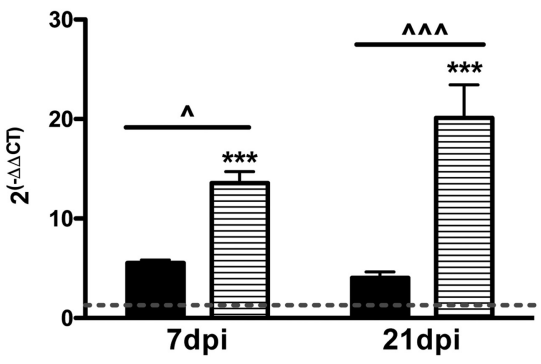

C

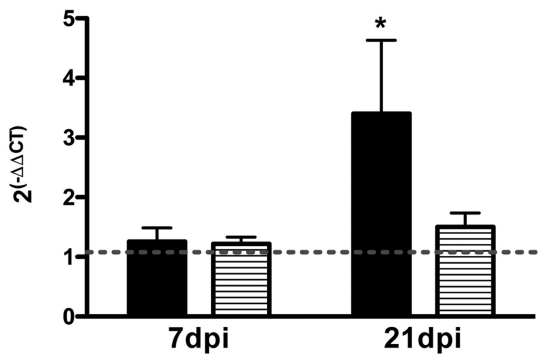

B

FGF2 mRNA

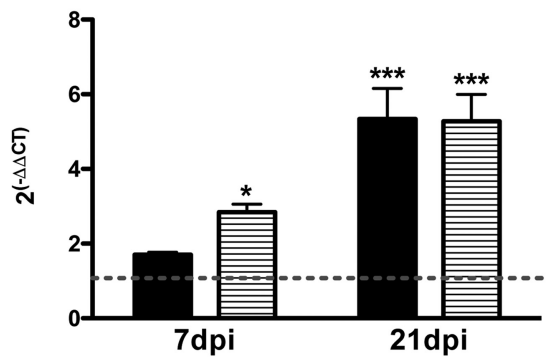

IL1 $\beta$ mRNA

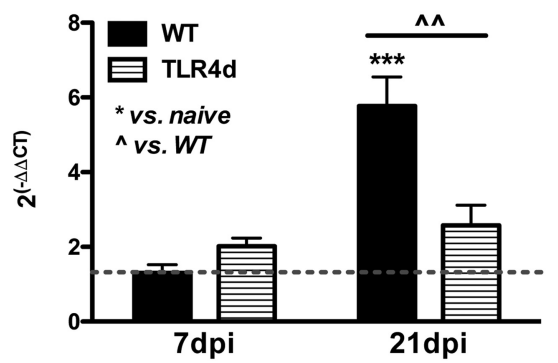

Figure 7. Gene expression of factors known to influence $0 \mathrm{~L}$ lineage cell survival or fate are altered after injury in TLR4d mice during peak oligodendrogenesis. qRT-PCR on a $5 \mathrm{~mm}$ section of injured spinal cord centered on the lesion epicenter measured mRNA expression of IGF $(\boldsymbol{A})$, FGF2 (B), PDGF-A $(\boldsymbol{C})$, and IL-1 $\beta(\boldsymbol{D})$. ---indicates naive. ${ }^{*} p<0.05,{ }^{* * *} p<0.001$ versus naive; $\wedge p<$ $0.05, \wedge \wedge p<0.01, \wedge \wedge \wedge p<0.001$ versus WT. Data are mean \pm SEM.

BMPs and TGF $\beta$ signaling can induce expression of inhibitor of differentiation (ID) molecules (Samanta and Kessler, 2004; Cheng et al., 2007; Lasorella et al., 2014). Both ID2 and ID4 are cell-intrinsic inhibitors of OL differentiation, and both have been 
A

BMP4 mRNA

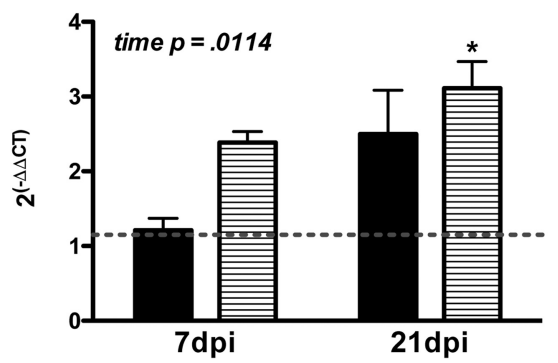

C

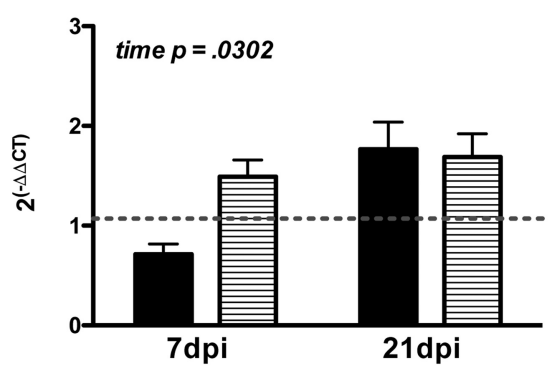

B

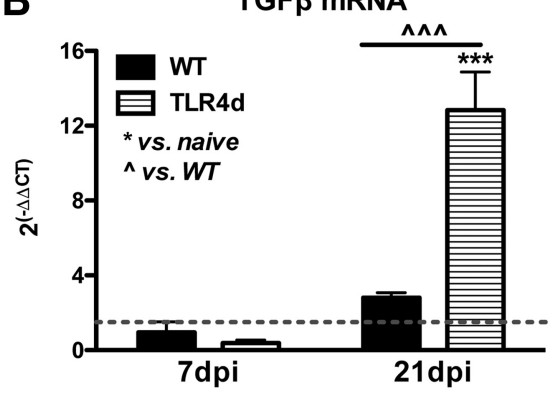

D

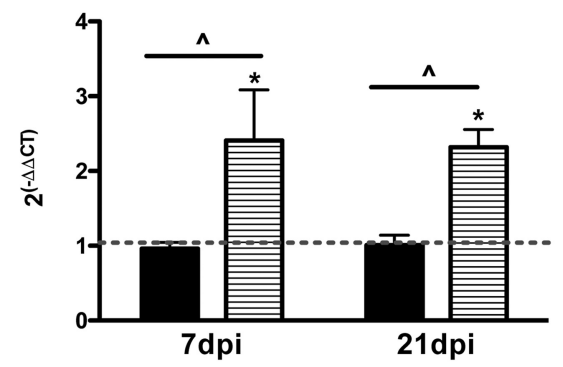

Figure 8. Inhibitors of $0 \mathrm{~L}$ differentiation are increased after SCl in TLR4d mice. qRT-PCR on a $5 \mathrm{~mm}$ section of injured spinal cord centered on the lesion epicenter measured mRNA expression of BMP4 (A), $\operatorname{TGF} \beta(\boldsymbol{B}), \operatorname{ID2}(\boldsymbol{C})$, and ID4 (D). ---- indicates naive. ${ }^{*} p<$ $0.05,{ }^{* * *} p<0.001$ versus naive; $\wedge p<0.05, \wedge \wedge \wedge p<0.001$ versus WT. Data are mean \pm SEM.

shown to rise chronically after SCI (Hesp et al., 2015). ID2 mRNA was twice as high in TLR4d tissue at $7 \mathrm{dpi}$; by $21 \mathrm{dpi}$, WT ID2 had increased comparably (Fig. 8C). ID4 RNA expression was significantly greater in TLR4d spinal cords at 7 and 21 dpi compared with WTs and uninjured controls $(p<0.05$ vs WT and naive; Fig. $8 D)$. Collectively, these data show elevated BMP4, TGF $\beta$, and ID4 mRNA in the TLR4d spinal cords after injury. Thus, TLR4 may function normally to keep levels of these inhibitors of OL differentiation low after SCI.

\section{Discussion}

This work demonstrates that TLR4 signaling is essential for maximal sparing and replacement of OL lineage cells after SCI. Acutely, TLR4d tissue lost significantly more OLs and NG2 cells compared with WT. This was despite comparable injury severities, lesion sizes, and intraspinal bleeding. However, other notable differences were detected between TLR4d and WT injured spinal cords that might be related to greater acute cell loss. One example was significantly lower ferritin expression $1 \mathrm{dpi}$ in TLR4d cords, which is required for safe iron storage. Because overall iron levels were comparable in both groups, the blunted ferritin response in TLR4d lesions would reduce the typically robust post-SCI iron sequestration by macrophages (Sauerbeck et al., 2013). Iron is highly reactive, and iron sequestration by macrophages protects nearby cells from iron-induced oxidative damage (Olakanmi et al., 1993). Therefore, it is possible that excess free iron in TLR4d cords could lead to a more toxic injury milieu that would exacerbate loss of vulnerable cells such as OLs. TLR4 activation can stimulate ferritin gene expression (Torti and Torti, 2002; Zhang et al., 2005). Thus, it is likely that TLR4 activation is an early post-SCI trigger for stimulating ferritin expression by microglia and macrophages.

OL numbers rebound after SCI, rising from a significant loss at 1 dpi back to baseline within 1-2 weeks, which was confirmed here in WT and TLR4d animals. This occurred despite the lower number of $\mathrm{NG} 2{ }^{+}$OPCs in acute TLR4d spinal cords, suggesting that the remaining cells overcame this deficit and differentiated into OLs over the first week after injury. In WT mice at 7-21 dpi, the number of OLs rose beyond naive levels, confirming previous studies (Tripathi and McTigue, 2007; Hesp et al., 2015). However, this chronic increase in OLs was absent in TLR4d injured spinal cords, which is consistent with their lower number of new $\left(\mathrm{BrdU}^{+}\right)$ OLs at 14 dpi. Previous worked showed that new OLs generated 2-8 weeks after SCI myelinate spinal axons for at least 3 months after injury, revealing an important contribution to endogenous repair (Hesp et al., 2015). The lack of chronic rise in OLs in TLR4d spinal cords implicates TLR4 signaling in promoting or sustaining chronic oligodendrogenesis after SCI.

The hampered oligogenic response after SCI may be the result of a combination of differences between TLR4d and WT spinal cords. First, we demonstrate that TLR4 activation stimulates myelin debris phagocytosis in vitro and that a lack of TLR4 hampered lipid debris clearance from the injury site in vivo. This fits with previous observations demonstrating that TLR4 activation accelerates macrophage debris phagocytosis (Vallières et al., 2006; Boivin et al., 2007; Li et al., 2014; Rajbhandari et al., 2014) and indicates that TLR4 is necessary to facilitate phagocytic removal of myelin and other debris from the injured area. Myelin debris inhibits OL differentiation, making debris removal essential for optimal post-SCI OL replacement (Robinson and Miller, 1999; Kotter et al., 2006; Plemel et al., 2013). Furthermore, myelin-laden macrophages have an anti-inflammatory phenotype (Boven et al., 2006; van Rossum et al., 2008; Bogie et al., 2013; Kroner et al., 2014; Wang et al., 2015). Thus, in addition to reduced debris clearance in TLR4d mice, reduced macrophage phagocytosis may impair a phenotypic switch in macrophages that supports chronic oligodendrogenesis and tissue repair.

Lack of TLR4 signaling after SCI also markedly altered mRNA expression of several factors known to affect OL lineage cell fate and survival. At 7 dpi, IGF-1, FGF-2, and ID4 mRNA were all significantly higher in TLR4d spinal cords. Collectively, this combination would hamper OPC cell cycle exit and differentiation, which is consistent with the reduced number of $\mathrm{BrdU}^{+} \mathrm{OLs}$ derived from OPCs proliferating during the first week after injury in TLR4d tissue. The marked increase in IGF-1 in TLR4d tissue is in accord with work showing that TLR4 activation decreases IGF-1 expression by microglia (Pang et al., 2010; Suh et al., 2013). After SCI in WTs, endogenous TLR4 ligands may similarly suppress IGF-1 expression in the injured spinal cord. As stated above, the combination of IGF-1 and FGF-2 promotes cell cycle entry by OPCs (Jiang et al., 2001; Frederick and Wood, 2004; Frederick et al., 2007), and FGF-2 alone can prevent OL differentiation (McKinnon et al., 1990).

By $21 \mathrm{dpi}$, IGF-1, TGF $\beta$, BMP4, and ID4 expression was increased whereas PDGF-A and IL-1 $\beta$ expression was decreased in 
TLR4d spinal cords. Although factors such as IGF- 1 and TGF $\beta$ can enhance OL survival and differentiation, the balance of the environment, with lower PDGF-A and IL- $1 \beta$ and elevated BMP4 and ID4 (and likely additional changes not tested), must have been such that the long-term "oligogenic" nature of the TLR4d injured spinal cords was reduced. BMP signaling can induce expression of IDs, which in turn inhibit OL genesis. As their name suggests, ID proteins in general reduce differentiation of various progenitor cells (Ling et al., 2014). ID4 in particular inhibits OL differentiation by sequestering Olig transcription factors in the cytoplasm, thereby preventing transcription of genes needed for OL maturation (Samanta and Kessler, 2004; See and Grinspan, 2009). Interestingly, TLR4 signaling can reduce BMP2 and ID4 expression in bone (Yang et al., 2014). Our results suggest that it may be an endogenous regulator of IDs and BMPs in the CNS as well.

In addition to lower OL numbers, the normally robust increase in NG2 expression after SCI was tempered in TLR4d tissue. NG2 proteoglycan is expressed on OPCs and pericytes (for review, see Stallcup, 2002) and also by infiltrating nonmyelinating Schwann cells and macrophages within the lesions (Jones et al., 2002; McTigue et al., 2006). In addition to being expressed on the cell surface, NG2 can be cleaved and accumulate extracellularly (Nishiyama et al., 1995; Sakry et al., 2014) and may contribute to glial scarring along lesion borders. Here we noted reduced overall NG2 expression and a marked difference in NG2 cell morphology around the lesions. Because oligodendrogenesis is most prominent along lesion borders (Tripathi and McTigue, 2007), reduced overall NG2 reactivity could signify a reduced or dystrophic population of OPCs available for OL production in TLR4d spinal cords. In addition, NG2 facilitates signaling of several growth factors in OPCs (Nishiyama et al., 1996; Goretzki et al., 1999; Grako et al., 1999). Therefore, growth factor effects on OPCs may have been impaired as a result of insufficient NG2, potentially explaining why enhanced expression of some growth factors was not associated with increased OL genesis.

A final potential contributor to reduced OL generation is the lower axon number detected at 21 and 42 dpi in TLR4d tissue. This extends the work by Kigerl et al. (2007) who detected reduced white matter sparing in TLR4d SCI tissue; the current data show the loss is not only to myelin but extends to axons as well. Axons can regulate OPC responses, and the lower number of surviving or sprouting axons in TLR4d tissue may have provided a reduced drive for chronic OPC proliferation and OL differentiation, at least in that region. This highlights the need for understanding the role of TLR4 in acute neuroprotection and in debris removal because myelin debris not only reduces OL genesis but also inhibits axon growth.

These results detailing reduced cell replacement and hampered debris cleanup indicate that TLR4 signaling plays an important and ongoing role in CNS lesion resolution. TLR4 signaling after SCI is most likely mediated through microglia and macrophages as they maintain high TLR4 expression (Kigerl et al., 2007). Despite being a "sterile" lesion, many ligands are present in the injury environment that can activate TLR4, such as heme, HMGB1, and fibronectin (Kigerl and Popovich, 2009). Absence of TLR4 signaling in microglia and macrophages after SCI likely altered their functions, which in turn may have affected the function of other cellular constituents, such as astrocytes, which produce many of the growth factors measured here. Glial scar formation by astrocytes is markedly defective in TLR4d spinal cords after SCI, and this in turn is thought to have allowed entry of activated macrophages into spared white matter (Kigerl et al., 2007). Results here show that the typically robust NG2 cell response within the glial scar was also abrogated, which could have contributed to faulty lesion containment. This collectively confirms that TLR4 signaling positively regulates glial scar formation after SCI.

In summary, this work expands the roles of TLR4 signaling after SCI to include regulating survival of OLs, OPCs, and axons, promoting OL replacement, facilitating debris clearance, and regulating growth factor mRNA and ferritin expression. This highlights the integral role of inflammatory cells in an array of CNS injury processes essential for lesion stabilization and tissue repair. It also shows the complex and interrelated roles of the cellular constituents within the injured spinal cord, in that preventing signaling from a single receptor on one cell type dramatically altered the lesion microenvironment and cellular responses of multiple other cells. Last, it adds to our knowledge of regulatory mechanisms important for reducing death of OL lineage cells and enhancing their replacement in the injured adult CNS.

\section{References}

Aderem A, Ulevitch RJ (2000) Toll-like receptors in the induction of the innate immune response. Nature 406:782-787. CrossRef Medline

Almad A, Sahinkaya FR, McTigue DM (2011) Oligodendrocyte fate after spinal cord injury. Neurotherapeutics 8:262-273. CrossRef Medline

Basso DM, Fisher LC, Anderson AJ, Jakeman LB, McTigue DM, Popovich PG (2006) Basso mouse scale for locomotion detects differences in recovery after spinal cord injury in five common mouse strains. J Neurotrauma 23:635-659. CrossRef Medline

Bogie JF, Jorissen W, Mailleux J, Nijland PG, Zelcer N, Vanmierlo T, Van Horssen J, Stinissen P, Hellings N, Hendriks JJ (2013) Myelin alters the inflammatory phenotype of macrophages by activating PPARs. Acta Neuropathol Commun 1:43. CrossRef Medline

Boivin A, Pineau I, Barrette B, Filali M, Vallières N, Rivest S, Lacroix S (2007) Toll-like receptor signaling is critical for Wallerian degeneration and functional recovery after peripheral nerve injury. J Neurosci 27:1256512576. CrossRef Medline

Boven LA, Van Meurs M, Van Zwam M, Wierenga-Wolf A, Hintzen RQ, Boot RG, Aerts JM, Amor S, Nieuwenhuis EE, Laman JD (2006) Myelinladen macrophages are anti-inflammatory, consistent with foam cells in multiple sclerosis. Brain 129:517-526. CrossRef Medline

Burgess AW, Metcalf D, Kozka IJ, Simpson RJ, Vairo G, Hamilton JA, Nice EC (1985) Purification of two forms of colony-stimulating factor from mouse L-cell-conditioned medium. J Biol Chem 260:16004-16011. Medline

Carraway MS, Ghio AJ, Taylor JL, Piantadosi CA (1998) Induction of ferritin and heme oxygenase-1 by endotoxin in the lung. Am J Physiol 275: L583-L592. Medline

Chen J, Leong SY, Schachner M (2005) Differential expression of cell fate determinants in neurons and glial cells of adult mouse spinal cord after compression injury. Eur J Neurosci 22:1895-1906. CrossRef Medline

Cheng X, Wang Y, He Q, Qiu M, Whittemore SR, Cao Q (2007) Bone morphogenetic protein signaling and olig $1 / 2$ interact to regulate the differentiation and maturation of adult oligodendrocyte precursor cells. Stem Cells 25:3204-3214. CrossRef Medline

Crowe MJ, Bresnahan JC, Shuman SL, Masters JN, Beattie MS (1997) Apoptosis and delayed degeneration after spinal cord injury in rats and monkeys. Nat Med 3:73-76. CrossRef Medline

Frederick TJ, Wood TL (2004) IGF-I and FGF-2 coordinately enhance cyclin D1 and cyclin E-cdk2 association and activity to promote G1 progression in oligodendrocyte progenitor cells. Mol Cell Neurosci 25:480-492. CrossRef Medline

Frederick TJ, Min J, Altieri SC, Mitchell NE, Wood TL (2007) Synergistic induction of cyclin D1 in oligodendrocyte progenitor cells by IGF-I and FGF-2 requires differential stimulation of multiple signaling pathways. Glia 55:1011-1022. CrossRef Medline

Goretzki L, Burg MA, Grako KA, Stallcup WB (1999) High-affinity binding of basic fibroblast growth factor and platelet-derived growth factor-AA to the core protein of the NG2 proteoglycan. J Biol Chem 274:16831-16837. CrossRef Medline

Grako KA, Ochiya T, Barritt D, Nishiyama A, Stallcup WB (1999) PDGF 
(alpha)-receptor is unresponsive to PDGF-AA in aortic smooth muscle cells from the NG2 knockout mouse. J Cell Sci 112:905-915. Medline

Grossman SD, Rosenberg LJ, Wrathall JR (2001) Temporal-spatial pattern of acute neuronal and glial loss after spinal cord contusion. Exp Neurol 168:273-282. CrossRef Medline

Hampton DW, Asher RA, Kondo T, Steeves JD, Ramer MS, Fawcett JW (2007) A potential role for bone morphogenetic protein signalling in glial cell fate determination following adult central nervous system injury in vivo. Eur J Neurosci 26:3024-3035. CrossRef Medline

Hendrickx DA, Schuurman KG, van Draanen M, Hamann J, Huitinga I (2014) Enhanced uptake of multiple sclerosis-derived myelin by THP-1 macrophages and primary human microglia. J Neuroinflammation 11:64. CrossRef Medline

Hesp ZC, Goldstein EZ, Miranda CJ, Kaspar BK, McTigue DM (2015) Chronic oligodendrogenesis and remyelination after spinal cord injury in mice and rats. J Neurosci 35:1274-1290. CrossRef Medline

Huang RL, Yuan Y, Zou GM, Liu G, Tu J, Li Q (2014) LPS-stimulated inflammatory environment inhibits BMP-2-induced osteoblastic differentiation through crosstalk between TLR4/MyD88/NF- $\kappa$ B and BMP/Smad signaling. Stem Cells Dev 23:277-289. CrossRef Medline

Jiang F, Frederick TJ, Wood TL (2001) IGF-I synergizes with FGF-2 to stimulate oligodendrocyte progenitor entry into the cell cycle. Dev Biol 232: 414-423. CrossRef Medline

Jones LL, Yamaguchi Y, Stallcup WB, Tuszynski MH (2002) NG2 is a major chondroitin sulfate proteoglycan produced after spinal cord injury and is expressed by macrophages and oligodendrocyte progenitors. J Neurosci 22:2792-2803. Medline

Kigerl KA, Popovich PG (2009) Toll-like receptors in spinal cord injury. Curr Top Microbiol Immunol 336:121-136. CrossRef Medline

Kigerl KA, Lai W, Rivest S, Hart RP, Satoskar AR, Popovich PG (2007) Tolllike receptor (TLR)-2 and TLR-4 regulate inflammation, gliosis, and myelin sparing after spinal cord injury. J Neurochem 102:37-50. CrossRef Medline

Kotter MR, Zhao C, van Rooijen N, Franklin RJ (2005) Macrophagedepletion induced impairment of experimental CNS remyelination is associated with a reduced oligodendrocyte progenitor cell response and altered growth factor expression. Neurobiol Dis 18:166-175. CrossRef Medline

Kotter MR, Li WW, Zhao C, Franklin RJ (2006) Myelin impairs CNS remyelination by inhibiting oligodendrocyte precursor cell differentiation. J Neurosci 26:328-332. CrossRef Medline

Kroner A, Greenhalgh AD, Zarruk JG, Passos Dos Santos R, Gaestel M, David S (2014) TNF and increased intracellular iron alter macrophage polarization to a detrimental M1 phenotype in the injured spinal cord. Neuron 83:1098-1116. CrossRef Medline

Lasorella A, Benezra R, Iavarone A (2014) The ID proteins: master regulators of cancer stem cells and tumour aggressiveness. Nat Rev Cancer 14:77-91. CrossRef Medline

Layoun A, Santos MM (2012) Bacterial cell wall constituents induce hepcidin expression in macrophages through MyD88 signaling. Inflammation 35:1500-1506. CrossRef Medline

Lehnardt S, Lachance C, Patrizi S, Lefebvre S, Follett PL, Jensen FE, Rosenberg PA, Volpe JJ, Vartanian T (2002) The toll-like receptor TLR4 is necessary for lipopolysaccharide-induced oligodendrocyte injury in the CNS. J Neurosci 22:2478-2486. Medline

Li HJ, Zhang X, Zhang F, Wen XH, Lu LJ, Shen J (2014) Enhanced repair effect of Toll-like receptor 4 activation on neurotmesis: assessment using MR neurography. AJNR Am J Neuroradiol 35:1608-1614. CrossRef Medline

Ling F, Kang B, Sun XH (2014) Id proteins: small molecules, mighty regulators. Curr Top Dev Biol 110:189-216. CrossRef Medline

Longbrake EE, Lai W, Ankeny AP, Popovich PG (2007) Characterization and modeling of monocyte-derived macrophages after spinal cord injury. J Neurochem 102:1083-1094. CrossRef Medline

Mason JL, Suzuki K, Chaplin DD, Matsushima GK (2001) Interleukin-1 $\beta$ promotes repair of the CNS. J Neurosci 21:7046-7052. Medline

McKinnon RD, Matsui T, Dubois-Dalcq M, Aaronson SA (1990) FGF modulates the PDGF-driven pathway of oligodendrocyte development. Neuron 5:603-614. CrossRef Medline

McMorris FA, McKinnon RD (1996) Regulation of oligodendrocyte development and CNS myelination by growth factors: prospects for therapy of demyelinating disease. Brain Pathol 6:313-329. CrossRef Medline
McTigue DM, Tripathi RB (2008) The life, death, and replacement of oligodendrocytes in the adult CNS. J Neurochem 107:1-19. CrossRef Medline

McTigue DM, Wei P, Stokes BT (2001) Proliferation of NG2-positive cells and altered oligodendrocyte numbers in the contused rat spinal cord. J Neurosci 21:3392-3400. Medline

McTigue DM, Tripathi R, Wei P (2006) NG2 colocalizes with axons and is expressed by a mixed cell population in spinal cord lesions. J Neuropathol Exp Neurol 65:406-420. CrossRef Medline

Nishiyama A, Lin XH, Stallcup WB (1995) Generation of truncated forms of the NG2 proteoglycan by cell surface proteolysis. Mol Biol Cell 6: 1819-1832. CrossRef Medline

Nishiyama A, Lin XH, Giese N, Heldin CH, Stallcup WB (1996) Interaction between NG2 proteoglycan and PDGF alpha-receptor on O2A progenitor cells is required for optimal response to PDGF. J Neurosci Res 43: 315-330. CrossRef Medline

Noble LJ, Wrathall JR (1989) Distribution and time course of protein extravasation in the rat spinal cord after contusive injury. Brain Res 482 : 57-66. CrossRef Medline

Norton WT, Poduslo SE (1973) Myelination in rat brain: method of myelin isolation. J Neurochem 21:749-757. CrossRef Medline

Olakanmi O, McGowan SE, Hayek MB, Britigan BE (1993) Iron sequestration by macrophages decreases the potential for extracellular hydroxyl radical formation. J Clin Invest 91:889-899. CrossRef Medline

Pang Y, Campbell L, Zheng B, Fan L, Cai Z, Rhodes P (2010) Lipopolysaccharide-activated microglia induce death of oligodendrocyte progenitor cells and impede their development. Neuroscience 166:464475. CrossRef Medline

Plemel JR, Manesh SB, Sparling JS, Tetzlaff W (2013) Myelin inhibits oligodendroglial maturation and regulates oligodendrocytic transcription factor expression. Glia 61:1471-1487. CrossRef Medline

Poltorak A, He X, Smirnova I, Liu MY, Van Huffel C, Du X, Birdwell D, Alejos E, Silva M, Galanos C, Freudenberg M, Ricciardi-Castagnoli P, Layton B, Beutler B (1998) Defective LPS signaling in C3H/HeJ and C57BL/ 10ScCr mice: mutations in Tlr4 gene. Science 282:2085-2088. CrossRef Medline

Rajbhandari L, Tegenge MA, Shrestha S, Ganesh Kumar N, Malik A, Mithal A, Hosmane S, Venkatesan A (2014) Toll-like receptor 4 deficiency impairs microglial phagocytosis of degenerating axons. Glia 62:1982-1991. CrossRef Medline

Recalcati S, Locati M, Marini A, Santambrogio P, Zaninotto F, De Pizzol M, Zammataro L, Girelli D, Cairo G (2010) Differential regulation of iron homeostasis during human macrophage polarized activation. Eur J Immunol 40:824-835. CrossRef Medline

Robinson S, Miller RH (1999) Contact with central nervous system myelin inhibits oligodendrocyte progenitor maturation. Dev Biol 216:359-368. CrossRef Medline

Rosenberg LJ, Wrathall JR (1997) Quantitative analysis of acute axonal pathology in experimental spinal cord contusion. J Neurotrauma 14: 823-838. CrossRef Medline

Rosenberg SS, Powell BL, Chan JR (2007) Receiving mixed signals: uncoupling oligodendrocyte differentiation and myelination. Cell Mol Life Sci 64:3059-3068. CrossRef Medline

Sahni V, Mukhopadhyay A, Tysseling V, Hebert A, Birch D, Mcguire TL, Stupp SI, Kessler JA (2010) BMPRla and BMPR1b signaling exert opposing effects on gliosis after spinal cord injury. J Neurosci 30:1839-1855. CrossRef Medline

Sakry D, Neitz A, Singh J, Frischknecht R, Marongiu D, Binamé F, Perera SS, Endres K, Lutz B, Radyushkin K, Trotter J, Mittmann T (2014) Oligodendrocyte precursor cells modulate the neuronal network by activitydependent ectodomain cleavage of glial NG2. PLoS Biol 12:e1001993. CrossRef Medline

Samanta J, Kessler JA (2004) Interactions between ID and OLIG proteins mediate the inhibitory effects of BMP4 on oligodendroglial differentiation. Development 131:4131-4142. CrossRef Medline

Sauerbeck A, Schonberg DL, Laws JL, McTigue DM (2013) Systemic iron chelation results in limited functional and histological recovery after traumatic spinal cord injury in rats. Exp Neurol 248:53-61. CrossRef Medline Schmittgen TD, Livak KJ (2008) Analyzing real-time PCR data by the comparative CT method. Nat Protoc 3:1101-1108. CrossRef Medline

Schonberg DL, McTigue DM (2009) Iron is essential for oligodendrocyte genesis following intraspinal macrophage activation. Exp Neurol 218: 64-74. CrossRef Medline 
Schonberg DL, Popovich PG, McTigue DM (2007) Oligodendrocyte generation is differentially influenced by toll-like receptor (TLR) 2 and TLR4mediated intraspinal macrophage activation. J Neuropathol Exp Neurol 66:1124-1135. CrossRef Medline

Schonberg DL, Goldstein EZ, Sahinkaya FR, Wei P, Popovich PG, McTigue DM (2012) Ferritin stimulates oligodendrocyte genesis in the adult spinal cord and can be transferred from macrophages to NG2 cells in vivo. J Neurosci 32:5374-5384. CrossRef Medline

See JM, Grinspan JB (2009) Sending mixed signals: bone morphogenetic protein in myelination and demyelination. J Neuropathol Exp Neurol 68:595-604. CrossRef Medline

Stallcup WB (2002) The NG2 proteoglycan: past insights and future prospects. J Neurocytol 31:423-435. Medline

Suh HS, Zhao ML, Derico L, Choi N, Lee SC (2013) Insulin-like growth factor 1 and 2 (IGF1, IGF2) expression in human microglia: differential regulation by inflammatory mediators. J Neuroinflammation 10:37. CrossRef Medline

Theurl I, Theurl M, Seifert M, Mair S, Nairz M, Rumpold H, Zoller H, Bellmann-Weiler R, Niederegger H, Talasz H, Weiss G (2008) Autocrine formation of hepcidin induces iron retention in human monocytes. Blood 111:2392-2399. CrossRef Medline

Torti FM, Torti SV (2002) Regulation of ferritin genes and protein. Blood 99:3505-3516. CrossRef Medline

Tripathi R, McTigueDM (2007) Prominent oligodendrocyte genesis along the border of spinal contusion lesions. Glia 55:698-711. CrossRef Medline

Urrutia P, Aguirre P, Esparza A, Tapia V, Mena NP, Arredondo M, GonzálezBillault C, Núñez MT (2013) Inflammation alters the expression of DMT1, FPN1 and hepcidin, and it causes iron accumulation in central nervous system cells. J Neurochem 126:541-549. CrossRef Medline

Vallières N, Berard JL, David S, Lacroix S (2006) Systemic injections of lipopolysaccharide accelerates myelin phagocytosis during Wallerian degeneration in the injured mouse spinal cord. Glia 53:103-113. CrossRef Medline van Rossum D, Hilbert S, Strassenburg S, Hanisch UK, Brück W (2008) Myelin-phagocytosing macrophages in isolated sciatic and optic nerves reveal a unique reactive phenotype. Glia 56:271-283. CrossRef Medline

Wang X, Cao K, Sun X, Chen Y, Duan Z, Sun L, Guo L, Bai P, Sun D, Fan J, He X, Young W, Ren Y (2015) Macrophages in spinal cord injury: phenotypic and functional change from exposure to myelin debris. Glia 63: 635-651. CrossRef Medline

Warden P, Bamber NI, Li H, Esposito A, Ahmad KA, Hsu CY, Xu XM (2001) Delayed glial cell death following Wallerian degeneration in white matter tracts after spinal cord dorsal column cordotomy in adult rats. Exp Neurol 168:213-224. CrossRef Medline

Wells CA, Ravasi T, Faulkner GJ, Carninci P, Okazaki Y, Hayashizaki Y, Sweet M, Wainwright BJ, Hume DA (2003a) Genetic control of the innate immune response. BMC Immunol 4:5. CrossRef Medline

Wells CA, Ravasi T, Sultana R, Yagi K, Carninci P, Bono H, Faulkner G, Okazaki Y, Quackenbush J, Hume DA, Lyons PA; RIKEN GER Group; GSL Members (2003b) Continued discovery of transcriptional units expressed in cells of the mouse mononuclear phagocyte lineage. Genome Res 13:1360-1365. CrossRef Medline

Wu SC, Rau CS, Lu TH, Wu CJ, Wu YC, Tzeng SL, Chen YC, Hsieh CH (2013) Knockout of TLR4 and TLR2 impair the nerve regeneration by delayed demyelination but not remyelination. J Biomed Sci 20:62. CrossRef Medline

Yang F, Liu XB, Quinones M, Melby PC, Ghio A, Haile DJ (2002) Regulation of reticuloendothelial iron transporter MTP1 (Slc1la3) by inflammation. J Biol Chem 277:39786-39791. CrossRef Medline

Yang J, Su N, Du X, Chen L (2014) Gene expression patterns in bone following lipopolysaccharide stimulation. Cell Mol Biol Lett 19:611-622. CrossRef Medline

Zhang J, Stanton DM, Nguyen XV, Liu M, Zhang Z, Gash D, Bing G (2005) Intrapallidal lipopolysaccharide injection increases iron and ferritin levels in glia of the rat substantia nigra and induces locomotor deficits. Neuroscience 135:829-838. CrossRef Medline 